\title{
Caustic Precipitation of Plutonium using Gadolinium as the Neutron Poison for Disposition to High Level Waste (U)
}

\author{
M. G. Bronikowski \\ J. H. Gray \\ B. C. Hill \\ F. R. Graham \\ D. G. Karraker
}

May 3, 2002

Approved by:

A. M. Murray, Manager

Actinide Laboratory Programs

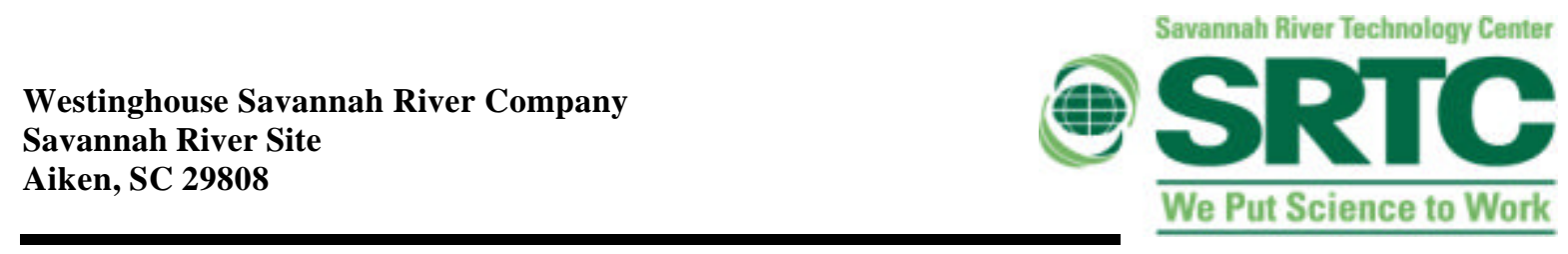

PREPARED FPR THE U. S. DEPARTMENT OF ENERGY UNDER CONTRACT NO. DE-AC09-96SR18500 


\section{DISCLAIMER}

This report was prepared as an account of work sponsored by an agency of the United States Government. Neither the United States Government nor any agency thereof, nor any of their employees, makes any warranty, express or implied, or assumes any legal liability or responsibility for the accuracy, completeness, or usefulness of any information, apparatus, product or process disclosed, or represents that its use would not infringe privately owned rights. Reference herein to any specific commercial product, process or service by trade name, trademark, manufacturer, or otherwise does not necessarily constitute or imply its endorsement, recommendation, or favoring by the United States Government or any agency thereof. The views and opinions of authors expressed herein do not necessarily state or reflect those of the United States Government or any agency thereof.

This report has been reproduced directly from the best available copy.

Available for sale to the public, in paper, from: U.S. Department of Commerce, National Technical Information Service, 5285 Port Royal Road, Springfield, VA 22161

phone: (800) 553-6847

fax: (703) 605-6900

email: orders@ntis.fedworld.gov

online ordering: http://www.ntis.gov/help/index.asp

Available electronically at http://www.osti.gov/bridge

Available for a processing fee to U.S. Department of Energy and its contractors, in paper, from: U.S. Department of Energy, Office of Scientific and Technical Information, P.O. Box 62, Oak Ridge, TN 37831-0062

phone: (865)576-8401

fax: (865)576-5728

email: reportseadonis.osti.gov 
WSRC-TR-2002-00198

Approvals

A. B. Beoniteownit

M. G. Bronikowski, Actinide Technology

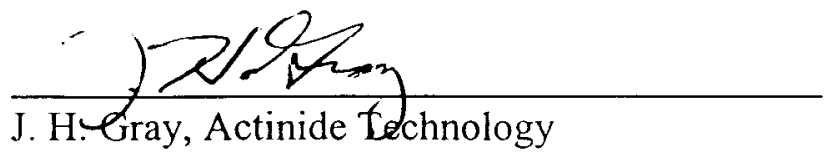

BOA CA

B. C. Hill, Actinide Technology

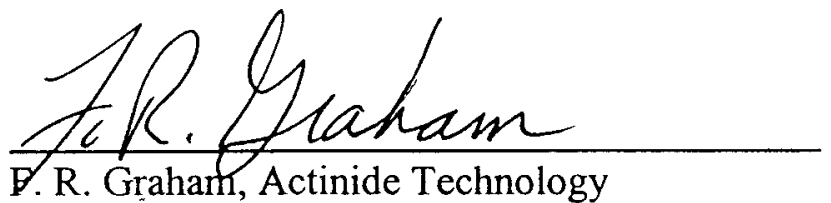

B. R. Graham, Actinide Technology

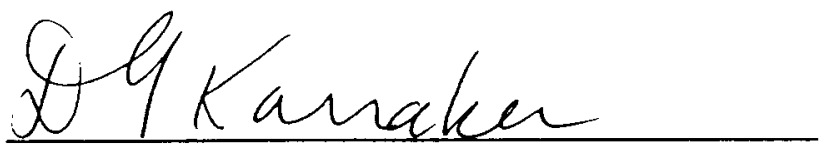

D. G. Karraker, Actinide Technology

$\frac{\text { Slue M. Massey }}{\text { A. M. Murray, Manager, Actinide Laboratory Programs }}$

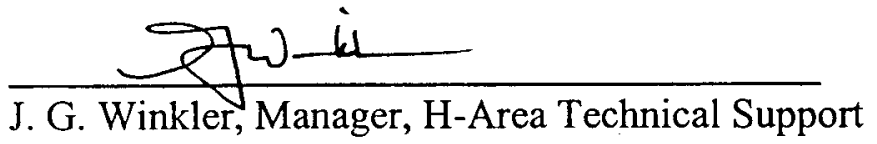

Mate $^{\text {May 2, } 2002}$

$\frac{5 / 3 / 02}{\text { Date }}$

$\frac{5 / 2 / 02}{\text { Date }}$

$\frac{\text { May 02,2002 }}{\text { Date }}$

$\frac{5 \operatorname{man} 02}{\text { Date }}$

Money 2, 2002

$\frac{5 / 02 / 02}{\text { Date }}$ 


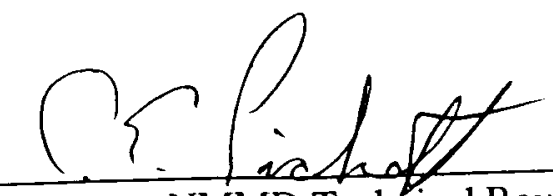

C. E. Pickett, NMMD Techfical Reviewer

$\frac{\text { S. Eaurinat, ATS Technical Reviewer }}{\text { J. L }}$ $\frac{\text { May 2,2002 }}{\text { Date }}$

$\frac{5-2-02}{\text { Date }}$ 


\section{TABLE OF CONTENTS}

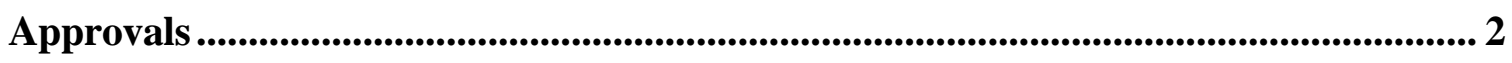

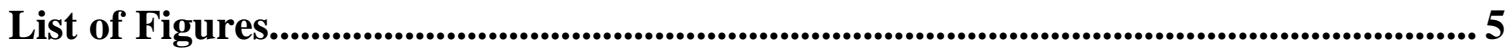

List of Tables........................................................................................................................ 5

Acronyms and Definitions .......................................................................................................... 6

Executive Summary ...................................................................................................................... 7

Summary ................................................................................................................................... 8

Background............................................................................................................................. 9

Historical Disposition of Pu to Waste ....................................................................... 9

Planned Disposal of Current Excess Plutonium............................................................... 9

Experimental Results and Discussion.................................................................................. 10

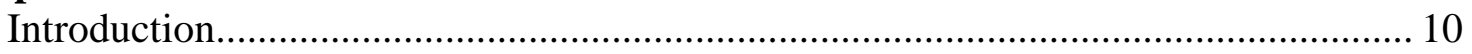

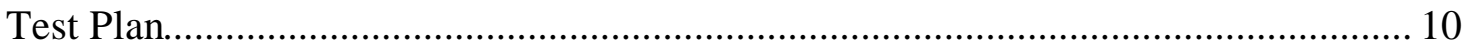

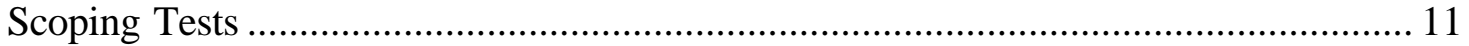

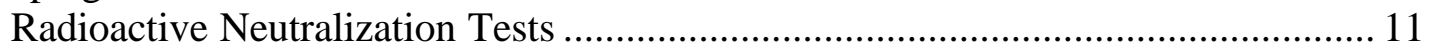

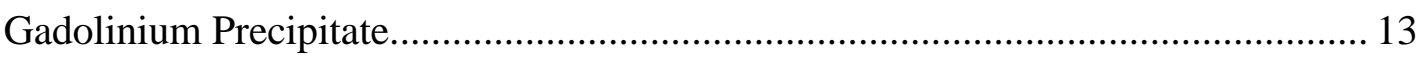

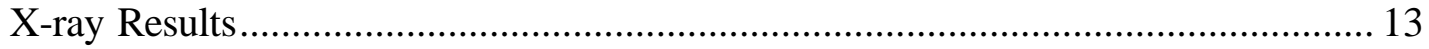

Baseline Process Experiments ..................................................................................... 17

Neutralization Experiments:.......................................................................... 17

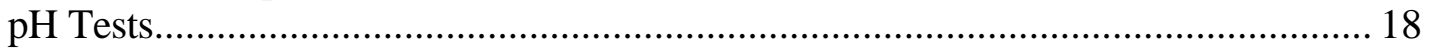

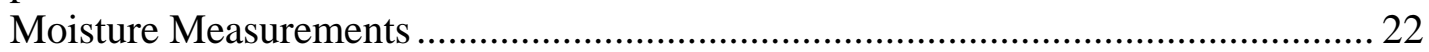

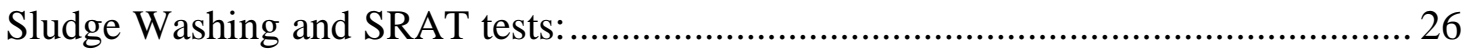

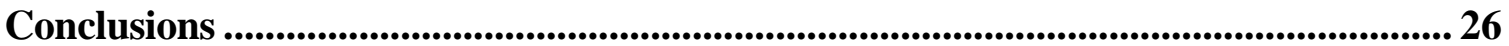

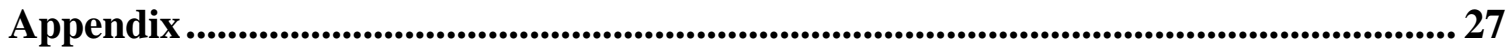

Appendix 1 Flow Sheets for Gd Addition and Neutralization....................................... 28

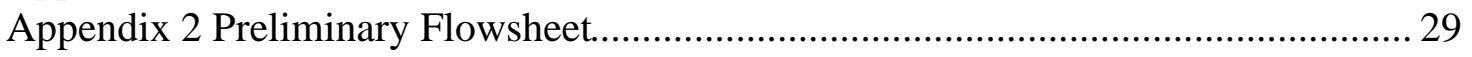

Appendix 3 Scoping Studies with Mn as Poison ...................................................... 30

Appendix 4 Test Plan for Gd/Pu Neutralization Tests................................................ 33

Appendix 5 Experimental Procedure to Determine Gd/Pu Ratio vs. pH....................... 34

Appendix 6 18.3 Pu/Gd Precipitates Contain Fe …………........................................ 35

Appendix 7 TGA Curve To Determine Moisture …………………..............................36

Appendix 8 Water Estimates of H-Canyon Precipitate.................................................. 37

Appendix 9 Neutralization Curves ......................................................................... 38

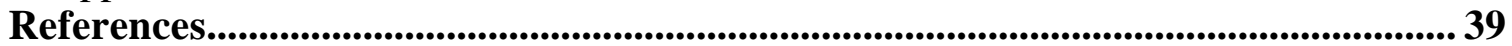




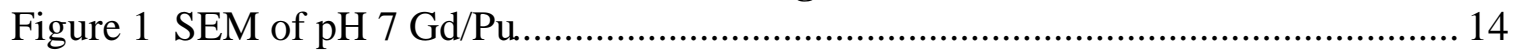

Figure 2 X-ray Spectra of Precipitate from Tank 16.3 and 18.3 ………........................ 15

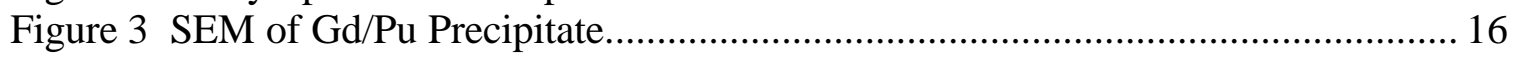

Figure 4 Precipitate Appearance vs. pH................................................................. 19

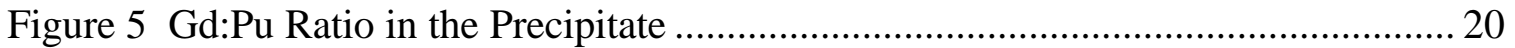

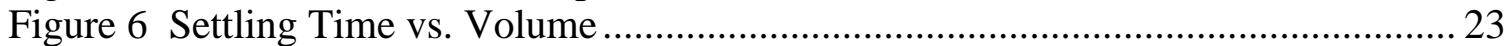

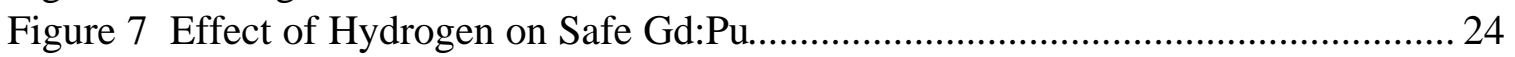

Figure 8 Agglomerated Particle Size in Microns ........................................................ 25

Figure 9 Agitated Particle Size in Microns .............................................................. 25

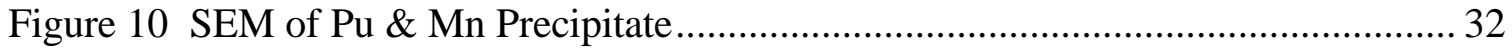

\section{List of Tables}

Table 1 Properties of Solutions in Plutonium Storage Tanks (3-20-02)......................... 11

Table 2 H-Canyon Simulant Runs ........................................................................ 12

Table 3 Final Weight Ratio of Neutralization Experiments............................................. 17

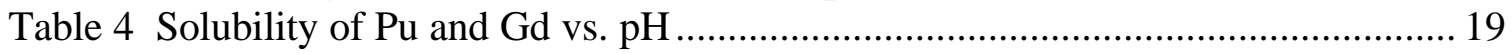

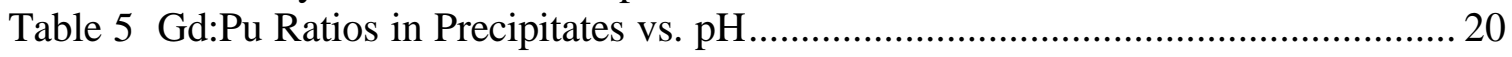

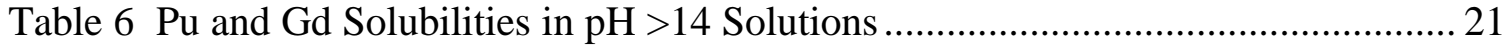

Table 7 Gadolinium to Plutonium Ratios in Re-dissolved Solids.................................... 21

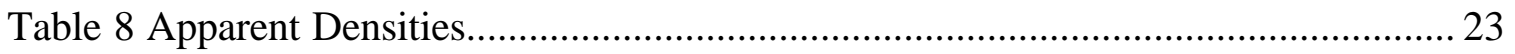

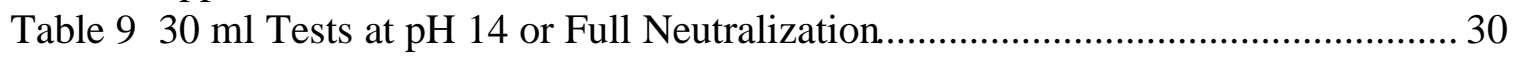

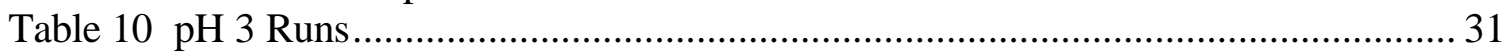

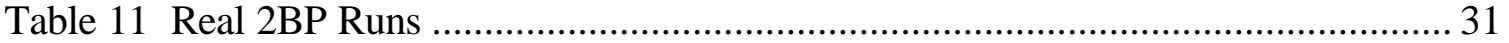


Acronyms and Definitions

2BP plutonium nitrate product stream from the PUREX process

DOE U S Department of Energy

DWPF Defense Waste Processing Facility

Dpm disintegrations per minute

HLW High Level Waste

ICP-ES Inductively Coupled Plasma-Emission Spectrometer

kg Kilogram

MOX Mixed OXide reactor fuel

NCSE Nuclear Criticality Safety Evaluation

NMMD Nuclear Materials Management Division

PUREX Plutonium and Uranium Extraction process

SEM Scanning Electron Microscope

SRAT Sludge Receipt and Adjustment Tank

SRTC Savannah River Technology Center

TGA ThermalGravimetric Analyzer

TSR Technical Safety Requirements

WSMS Westinghouse Safety Management Solutions

WSRC Westinghouse Savannah River Company

XRD X-Ray Diffraction 


\section{Executive Summary}

Nuclear Materials Management Division (NMMD) has proposed that up to $100 \mathrm{~kg}$ of the plutonium $(\mathrm{Pu})$ solutions stored in $\mathrm{H}$-Canyon be precipitated with a nuclear poison and dispositioned to H-Area Tank Farm. The use of gadolinium (Gd) as the poison would greatly reduce the number of additional glass logs resulting from this disposition.

This report summarizes the characteristics of the precipitation process and addresses criticality concerns in the Nuclear Criticality Safety Evaluation. No problems were found with the nature of the precipitate or the neutralization process.

Two criticality scenarios are of concern. The first is a concern that an inadequate amount of $\mathrm{Gd}$ precipitates with the $\mathrm{Pu}$ if the process is interrupted at $\mathrm{pH} 3$ (the point that $\mathrm{Pu}$ starts to form an insoluble polymer). Our experiments at this $\mathrm{pH}$ have determined that $5 \%$ $( \pm 1 \%)$ of the $\mathrm{Gd}$ precipitates with the formation of the first Pu. Determination of the water associated with this precipitate in the aqueous tank showed adequate hydrogen to $\mathrm{Pu}$ ratios, which makes the precipitate safe at the 0.05:1 ratio of $\mathrm{Gd}: \mathrm{Pu}$. The second scenario assumes that the precipitate slurry dries out in the Tank Farm transfer pump tank. Since there is no heat available, and the $\mathrm{Gd} / \mathrm{Pu}$ is hygroscopic, we have determined that adequate water is retained to thermalize neutrons and maintain the adequacy of Gd as a neutron poison. 


\section{Summary}

NMMD has proposed that some of the $\mathrm{Pu}$ solutions stored in H-Canyon could be precipitated with a nuclear poison and dispositioned to H-Area Tank Farm. The scope of the proposal is up to $100 \mathrm{~kg}$ of $\mathrm{Pu}$. To minimize the number of glass logs resulting from this process, NMMD plans to use gadolinium $(\mathrm{Gd})$ as the neutron poison. The $\mathrm{Gd}$ poisoned $\mathrm{Pu}$ solutions will also be neutralized at more than a critical mass unit to minimize the number of transfers to High Level Waste (HLW). The purpose of the Savannah River Technology Center (SRTC) test program was to produce experimental evidence to ensure the $\mathrm{Pu}$ would be homogeneously mixed with $\mathrm{Gd}$ in the precipitate to allow safe processing.

Because Gd is extremely effective in capturing thermal neutrons, but less effective in capturing fast neutrons, it is important that the $\mathrm{Pu}$ always have enough hydrogen present (in the form of water) for $\mathrm{Gd}$ to remain effective as a neutron poison. Results from centrifuged precipitates showed that the water present was more than adequate to maintain adequate poison at equal parts of $\mathrm{Gd} / \mathrm{Pu}$ by weight. This $1: 1$ ratio of $\mathrm{Gd}$ to $\mathrm{Pu}$ was chosen as the baseline flowsheet for the neutralization and precipitation.

Addition of $\mathrm{Gd}$ to samples from $\mathrm{Pu}$ storage tanks 12.1 and 18.3 was made without any immediate effect on the Pu solution. A sample of Tank 18.3 at 2:1 Gd:Pu ratio was stable for one month. Precipitation of $\mathrm{Gd} / \mathrm{Pu}$ from the 18.3 sample with $\mathrm{NaOH}$ was performed at bounding conditions of $0.5: 1,1: 1$ and $1.5: 1, \mathrm{Gd}: \mathrm{Pu}$ and 12.1 was precipitated at 2:1 $\mathrm{Gd}: \mathrm{Pu}$ without any problems. The precipitation step resulted in fine, easily dispersible particles. No high viscosity gel like material was noted as with the other poisons evaluated. SEM analyses showed an amorphous precipitate with both $\mathrm{Gd}$ and $\mathrm{Pu}$ present in all particles. Aged samples showed some crystals, which contained $\mathrm{Gd} / \mathrm{Pu}$, but an exact composition was not identified. Particle size of the material was measured under two conditions. The first was non-agitated, allowing agglomeration, and the second was agitated to break up agglomerents. The particle size distribution of both mixtures would be considered fine (small size) with agglomerated material between one and 210 microns (76\% below 60 microns) and the agitated material from $<1$ to 22 microns.

Additional study resulted from the partial neutralization of the $\mathrm{Gd} / \mathrm{Pu}$ solution. At $\mathrm{pH} 3$, most of the $\mathrm{Pu}$ precipitates as a polymer (at a slower rate vs. the precipitation at $\mathrm{pH}$ above 7 ), but only $5 \mathrm{wt} \%$ of the Gd is present in the precipitate. This partial precipitation of the $\mathrm{Gd}$ has been incorporated in the worst case scenario for the criticality safety analyses. This scenario is an operational concern, because by $\mathrm{pH} 7$ all the Gd precipitates with the $\mathrm{Pu}$ (NMMD should ensure that the addition does not stop at $\mathrm{pH} 3$ ). The time to transition from $\mathrm{pH} 3$ to $\mathrm{pH} 6.8$ will be less than a minute at the addition rate planned (less than 20 lb. of $50 \%$ wt or 19 molar $\mathrm{NaOH}$ ). Even in the unlikely event of agitator failure and neutralization stoppage at $\mathrm{pH} \mathrm{3}$, the ratio of $\mathrm{H}: \mathrm{Pu}: \mathrm{Gd}$ is adequate for neutron poison in the precipitate. The H:Pu was found to be greater than 1900:1, which is in the safe zone for $\mathrm{Gd}: \mathrm{Pu}$ precipitate at $\mathrm{pH}$ 3. If agitation is maintained, the $\mathrm{Pu}$ solids would be suspended and would behave like a solution and the soluble poison will protect the suspension from criticality. 
After the precipitate is transferred to the HLW Tank Farm, it will be mixed with sludge and washed with dilute caustic. The behavior of $\mathrm{Gd} / \mathrm{Pu}$ with the sludge and waste processing will be addressed in future reports.

\section{Background}

\section{Historical Disposition of Pu to Waste}

In the past, $\mathrm{Pu}$ has been dispositioned to the waste tanks in sub-critical mass units. The neutron poison used was either iron $(\mathrm{Fe})$ or depleted uranium (U) that was already present in the waste streams (either in the waste tanks or from the process activity that generated the $\mathrm{Pu}$ waste). Another poison that has been used is manganese $(\mathrm{Mn})$. Depleted U was used for disposition of the Pu/carbonate solutions generated in the solvent washer. Manganese has been used recently by H-Canyon to discard scrap Pu/U and LAP (Low Assay Pu) material but only at lower than a fissile mass unit with borated solutions. ${ }^{1,2}$

These three neutron poisons have a major disadvantage, because they generate a larger quantity of waste that ends up in DWPF glass. According to the Waste Acceptance Criteria ${ }^{3}$, to use $U$ as the poison, 198 grams ${ }^{238} \mathrm{U}$ per gram of fissile equivalent $\mathrm{Pu}$ must be used. For $\mathrm{Fe}, 160 \mathrm{gms}$ per gram of equivalent ${ }^{239} \mathrm{Pu}$ must be used and for $\mathrm{Mn}, 32$ grams per gram of equivalent ${ }^{239} \mathrm{Pu}$ must be used. An additional drawback stems from the large quantities of metal hydroxides produced upon neutralization. The hydroxide morphology limits the ability to precipitate and pump the desired amount of $\mathrm{Pu}$ in each batch. In the case of the $\mathrm{U}$, the physical mass of the $\mathrm{Pu} / \mathrm{U}$ slurry precludes large batches. In the case of $\mathrm{Fe}$, similar problems are encountered, compounded by the gelatinous nature of $\mathrm{Fe}(\mathrm{OH})_{3}$. Manganese looked desirable, because much less is required, but it was found that under certain conditions, the precipitate formed a gel in addition to being very viscous. This gel seemed to be reversible, but if it formed in the transfer line or jet, it would be a serious problem. In addition, the $\mathrm{Mn}(\mathrm{OH})_{2}$ produced air-oxidizes to form $\mathrm{Mn}_{2} \mathrm{O}_{3}$, which may be a potential mechanism for separation of the neutron poison from the $\mathrm{Pu}$.

\section{Planned Disposal of Current Excess Plutonium}

The team (consisting of experts from High Level Waste Division (HLWD), Defense Waste Processing Facility (DWPF), Nuclear Material Management Division (NMMD), Westinghouse Safety Management Solutions (WSMS) and SRTC) proposed that Gd be evaluated as the primary poison for excess $\mathrm{Pu}$ disposal, with $\mathrm{Mn}$ as a back-up. Since Gd has a very large cross section for thermal neutrons, a much smaller amount for poisoning is required in aqueous systems. However, the neutron absorption cross section falls off rapidly with unmoderated neutrons, and hydrogen (in the form of water) must be present for moderation in order for Gd to be much

more effective than the poisons used in the past. This neutron moderation must be 
maintained under all conditions, at least through the precipitation and transport to the waste tank. Since there is no credible means of drying out the precipitate, the team agreed that a centrifuged sample would represent a conservative "worst case" for moisture content in the precipitate. The worst case premise was based on the fact that air evaporation is very ineffective in drying gadolinium hydroxide, because it is very hygroscopic, and that there is no mechanism before the tank farm to force further drying. The precipitate could air dry in the pump transfer tank in the waste Tank Farm if transfer were interrupted for a long period.

\section{Experimental Results and Discussion}

\section{Introduction}

There are approximately $100 \mathrm{kgs}$. of excess Pu solution in H-Canyon that are outside the specifications for the planned MOX disposition path. The preferred option for this material is to transfer the Pu to HLW Tank 51, which will be used to make up the next sludge batch for DWPF. The result will be a slight increase in the $\mathrm{Pu}$ in the next sludge batch (from $\sim 0.005$ to $\sim 0.02 \mathrm{wt} \%$ ). In order to accomplish this disposition, the $\mathrm{Pu}$ must be precipitated with a suitable neutron poison to prevent any possible criticality. In the past, poisons such as depleted $\mathrm{U}, \mathrm{Fe}$ and $\mathrm{Mn}$ have been used. Scoping studies with Mn showed several potential problems (See Appendix 3). Iron and depleted U would create many extra glass logs increasing HLW costs.

Gadolinium can be used in much smaller ratios to $\mathrm{Pu}$ in an aqueous system and its use will result in an increase in volume of glass equivalent to less than one glass log. The experiments described in this report were designed to show that $\mathrm{Gd} / \mathrm{Pu}$ precipitate together to maintain an acceptable $\mathrm{Gd}: \mathrm{Pu}$ ratio and ensure that criticality is incredible.

\section{Test Plan}

A series of tests were planned to build on the findings from earlier scoping tests. The goal was to determine whether neutralization of a solution of $\mathrm{Gd}\left(\mathrm{NO}_{3}\right)_{3}$ and $\mathrm{Pu}\left(\mathrm{NO}_{3}\right)_{4}$ (with boron present) resulted in an intimate mixture of $\mathrm{Gd}$ and $\mathrm{Pu}$ species that cannot be separated by mechanical means or incidental chemical phenomena during further operations and transfers.

The effectiveness of Gd as a neutron poison is very dependent upon the energy of the neutrons. To be sure the $\mathrm{Pu}$ is protected with adequate neutron poison $(\mathrm{Gd})$ during the transfer to the Tank Farm, the precipitate was centrifuged and the water present was measured using a Thermal Gravimetric Analyzer (TGA). The scoping tests (results 1/18/02) showed that there were $\sim 30$ molecules of water (60 atoms of hydrogen) associated with a $\mathrm{Pu}$, gadolinium atom pair when precipitated in a 1:1 wt ratio after being centrifuged. The assumption for the initial criticality calculations was $>30$ hydrogen atoms per $\mathrm{Pu}$ atom ${ }^{9}$. This resulted in the proposed flow sheet that consists of a 1:1 ratio (by weight) of $\mathrm{Gd}$ to $\mathrm{Pu}$, which is over twice the amount of $\mathrm{Gd}$ needed for 30 hydrogen atoms per $\mathrm{Pu}$ atom. Later Calculations showed the atom .ratio for this precipitate to be $1: 1.52: 152 \mathrm{Pu}: \mathrm{Gd}: \mathrm{H}^{8}$ 


\section{Scoping Tests}

Scoping tests were run with $\mathrm{Mn} / \mathrm{Pu}$ and $\mathrm{Gd} / \mathrm{Pu}$, to determine if the predicted neutralization solubility and operability were acceptable at the ratios required for criticality control. Since Mn was not selected, results are summarized in Appendix 3.

Scoping tests were run with a real F-Canyon PUREX solution (2BP solution) and a simulated H-Canyon Pu solution. Further testing was done with actual samples of the $\mathrm{H}$-Canyon Pu solutions, now stored in tanks 18.3, 16.3, and 12.1 (Table 1). To be certain that there was nothing unusual about the $\mathrm{Gd}\left(\mathrm{NO}_{3}\right)_{3} \bullet 6 \mathrm{H}_{2} \mathrm{O}$ in storage, samples of that material were used for all the testing after the initial scoping tests.

Table 1 Properties of Solutions in Plutonium Storage Tanks (3-20-02)

\begin{tabular}{|l|l|l|l|l|l|l|l|}
\hline Tank no. & Net, lbs & Sp Grav & Acid, N & Pu, gpl & Pu, kg & Boron gpl & $\sim$ Vol, L \\
\hline 12.1 & 31,871 & 1.13 & 3.99 & 2.72 & 34.8 & 3.46 & 12,800 \\
\hline 18.3 & 69,554 & 1.16 & 5.19 & 2.0 & 54.4 & 2.92 & 27,200 \\
\hline 16.3 & 41,339 & 1.239 & 6.9 & 1.935 & 45.0 & NA & 23,253 \\
\hline
\end{tabular}

Since $\mathrm{pH}$ was found to be important for neutralizing with $\mathrm{Mn}$, a series of tests was planned with $\mathrm{pH}$ near 3,7 and 14 to characterize the $\mathrm{Gd}$ precipitate ratios. It was expected that the $\mathrm{Pu}$ and $\mathrm{Gd}$ would precipitate together, because lanthanide and actinide chemistries are very similar, and both produce nearly insoluble hydroxides. Analyses of the $\mathrm{Gd} / \mathrm{Pu}$ in the solids and solute were to be performed.

Physical characterization of the precipitate was done with the Scanning Electron Microscope (SEM) and X-ray Diffraction (XRD). Pu mass balance between supernate and solids was done by radiochemical methods. Gd concentrations were determined with ICP-ES. Particle size analyses were done by Laser Scattering. Settling rates were determined visually and by weight.

\section{Radioactive Neutralization Tests}

Neutralization tests were run with flowsheets provided by F-Canyon engineers, with a ratio of 1:1 $\mathrm{Gd}$ to Pu substituted for the Mn (Appendix, Table 10). The standard F \& H-Canyon neutralization procedure was followed. The Pu solution to be neutralized was added to a beaker along with the requisite amount of neutron poison from an acidic $\mathrm{Gd}\left(\mathrm{NO}_{3}\right)_{3} \bullet 6 \mathrm{H}_{2} \mathrm{O}$ solution. By using this acidic solution, no change in the $\mathrm{Pu}$ state in the samples was detected. 50 wt.\% $\mathrm{NaOH}$ was added with agitation so that the temperature was kept below $50^{\circ} \mathrm{C}$ and the final free hydroxide concentration was $>1.2 \mathrm{M}$. Deionized (DI) water was then added and the solution was left to react for two hours prior to sampling.

Partial neutralization tests were run in the same manner as full neutralization tests except that initially only part of the $50 \mathrm{wt} \% \mathrm{NaOH}$ was added. The solutions were allowed to react for two hours and sampled. After sampling, the rest of the 
$\mathrm{NaOH}$ was added to get to a concentration of $>1.2 \mathrm{M}$ followed by the addition of DI water (See Table 2).

Sampling of each neutralization test after the two-hour reaction period was done as follows. An aliquot of the mixed solution was pulled and centrifuged. The liquid phase was split into two parts. One part was to be analyzed by ICP-ES for elements $\mathrm{Gd}, \mathrm{U}$, and B. The other part was analyzed for its $\mathrm{Pu}$ concentration using radscreen and corrected for the Am activity using gamma scan results. The solids were washed with a $\mathrm{NaOH}$ solution of the same $\mathrm{pH}$ and $\mathrm{NO}_{3}{ }^{-}$concentration as the test solution and centrifuged. The solids were analyzed by XRD to determine compounds produced and SEM to determine the $\mathrm{Pu}$ and $\mathrm{Gd}$ distribution.

Further sampling took place 3-4 days, a week, and several weeks after the reactions were completed. A liquid supernate sample was taken after 3-4 days and analyzed by ICPES, Radscreen, and Gamma Scan. After a week, the solution was mixed and a sample was taken to obtain solids. The sample was centrifuged, washed, and analyzed by XRD and SEM. A final long-term supernate sample was taken after several weeks to determine the final $\mathrm{Pu}$ and $\mathrm{Gd}$ supernate concentrations (Results are shown in Table 4).

Table 2 H-Canyon Simulant Runs

\begin{tabular}{|c|c|c|c|c|c|c|}
\hline $\begin{array}{c}\mathrm{Gd}: \mathrm{Pu} \\
\mathrm{Ratio} \\
(\mathrm{pH})\end{array}$ & $\begin{array}{c}\mathrm{H}-\mathrm{Canyon} \text { simulant } \\
\text { (3g/L } / \mathrm{Lu}, 5 \mathrm{M} \\
\mathrm{HNO}_{3}, 4 \mathrm{~g} / \mathrm{L} \mathrm{B}, \\
3 \times 10^{-2} \mathrm{~g} / \mathrm{L} \mathrm{U}\end{array}$ & $\begin{array}{c}5.5 \mathrm{~g} / \mathrm{L} \mathrm{Gd} \\
\text { in } 1.22 \mathrm{M} \\
\mathrm{HNO}_{3}\end{array}$ & $\begin{array}{c}50 \mathrm{wt} \% \\
\mathrm{NaOH}\end{array}$ & DI water & $\mathrm{pH}$ & $\begin{array}{c}\text { Total } \\
\text { volume }\end{array}$ \\
\hline $1: 1(\mathrm{pH} 14)$ & $30 \mathrm{ml}$ & $16.2 \mathrm{ml}$ & $\begin{array}{c}9.75 \mathrm{ml} \\
+6.25 \mathrm{ml}\end{array}$ & $80 \mathrm{ml}$ & 3 & $\begin{array}{c}56.0 \mathrm{ml} \\
* 132 \mathrm{ml}\end{array}$ \\
\hline $1: 1(\mathrm{pH} 7)$ & $30 \mathrm{ml}$ & $16.2 \mathrm{ml}$ & $\begin{array}{c}9.50 \mathrm{ml} \\
+6.50 \mathrm{ml}\end{array}$ & $80 \mathrm{ml}$ & 7 & $\begin{array}{c}55.7 \mathrm{ml} \\
* 132 \mathrm{ml}\end{array}$ \\
\hline $1: 1(\mathrm{pH} 3)$ & $30 \mathrm{ml}$ & $16.2 \mathrm{ml}$ & $16 \mathrm{ml}$ & $80 \mathrm{ml}$ & 14 & $142 \mathrm{ml}$ \\
\hline
\end{tabular}

$* 10.5 \mathrm{ml}$ sampled prior to final neutralization and water addition 


\section{Gadolinium Precipitate}

The neutralized $\mathrm{Gd} / \mathrm{Pu}$ solutions produced a light green/brown, easily suspended precipitate. Physically, the precipitate behaved as reported in the literature for a coprecipitation of hydroxide compounds (i.e. $\mathrm{Pu}(\mathrm{OH})_{4}$ and $\left.\mathrm{Gd}(\mathrm{OH})_{3}\right)$. The literature indicates $\mathrm{Pu}$ is coprecipitated with a carrier compound in a purification process. Hydroxides coprecipitate with $\mathrm{Pu}(\mathrm{III})$ and $\mathrm{Pu}(\mathrm{IV})$ nearly quantitatively under the proper conditions. In our case, the conditions would be $>\mathrm{pH} \mathrm{7.}{ }^{4}$ The precipitate settled slowly when agitation was stopped. The precipitates re-suspended when agitation was resumed (provided by a standard magnetic laboratory stirring-bar in the beaker of precipitate and solute).

SEM analyses showed that all of the material produced in both the simulated runs and the 2BP run had both $\mathrm{Pu}$ and $\mathrm{Gd}$ present. This result is unlike the $\mathrm{Mn}$ case where $\mathrm{Pu}$ was found without $\mathrm{Mn}$ at $\mathrm{pH} 3$, and a large fraction of $\mathrm{Mn}$ was present as $\mathrm{Mn}(\mathrm{OH})_{2}$ and did not contain $\mathrm{Pu}$ (Appendix 3).

\section{X-ray Results}

The X-ray diffraction showed an amorphous structure with possible fits to $\mathrm{PuO}_{2}$ and $\mathrm{Gd}_{2} \mathrm{O}_{3}$. The $\mathrm{Pu}$ and $\mathrm{Gd}$ were so intimately mixed that the $\mathrm{x}$-ray patterns could not be resolved. The amorphous structure can be explained by the hydroxides being produced, which are not crystalline (See Figure 1). The crystal pattern, which came closest to the observed peaks, belonged to a mixed $\mathrm{Pu}, \mathrm{Gd}$ oxide structure (See Figure 2). When the $\mathrm{PuO}_{2}$ structure is assumed, a particle size of 20 microns or less was estimated. Resolution of these peaks could be attempted with heating of the solids to crystallize more of the material (Figure 3). If the $\mathrm{Gd}$ and $\mathrm{Pu}$ were mixed in uniform structure, a peak between the two expected peaks for an intermediate structure would possibly appear. Resolution of the structure would necessitate determining and comparing lattice dimensions. ${ }^{5}$ 
Figure 1 SEM of pH 7 Gd/Pu

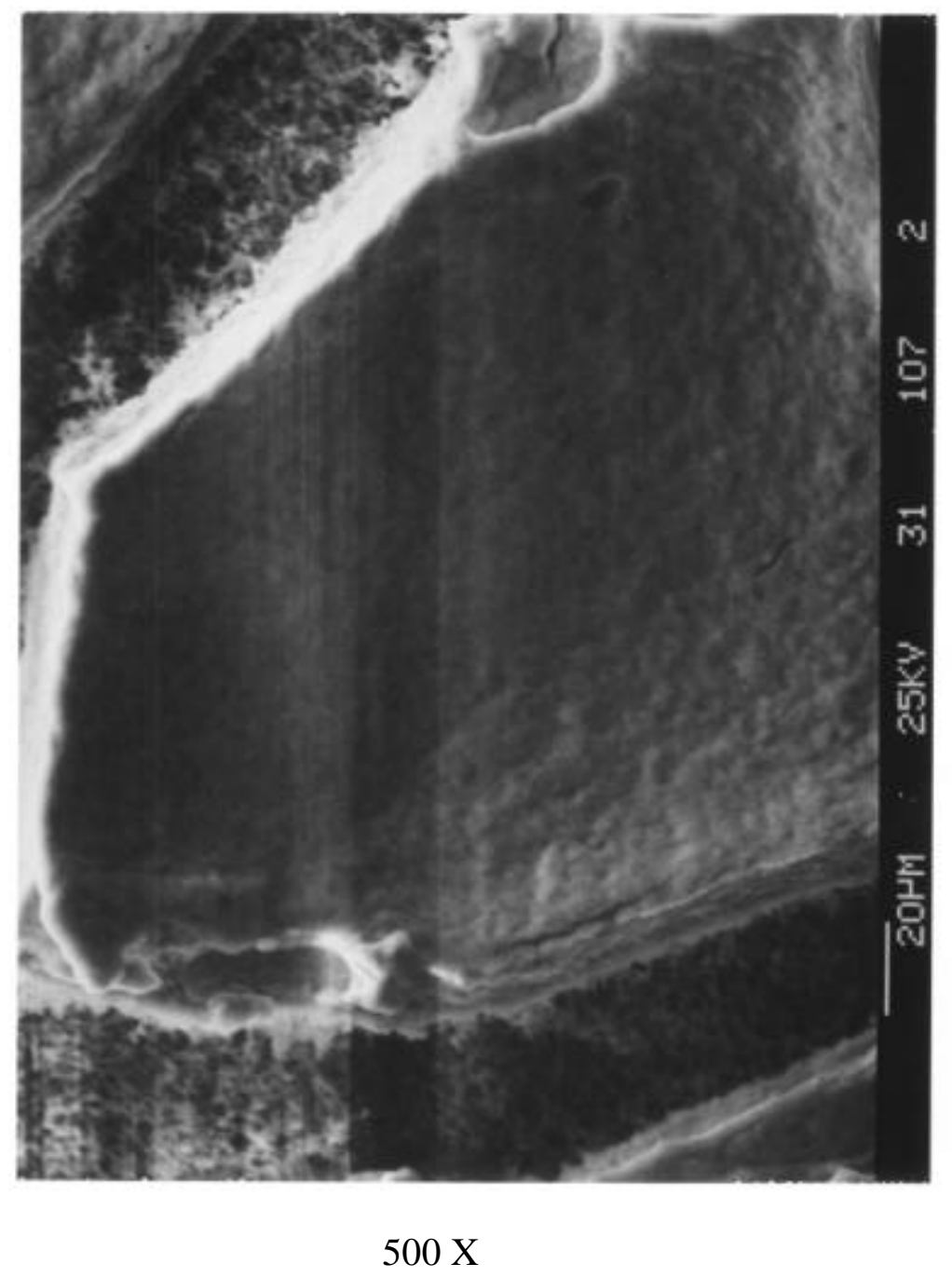


Figure 2 X-ray Spectra of Precipitate from Tank 16.3 and 18.3
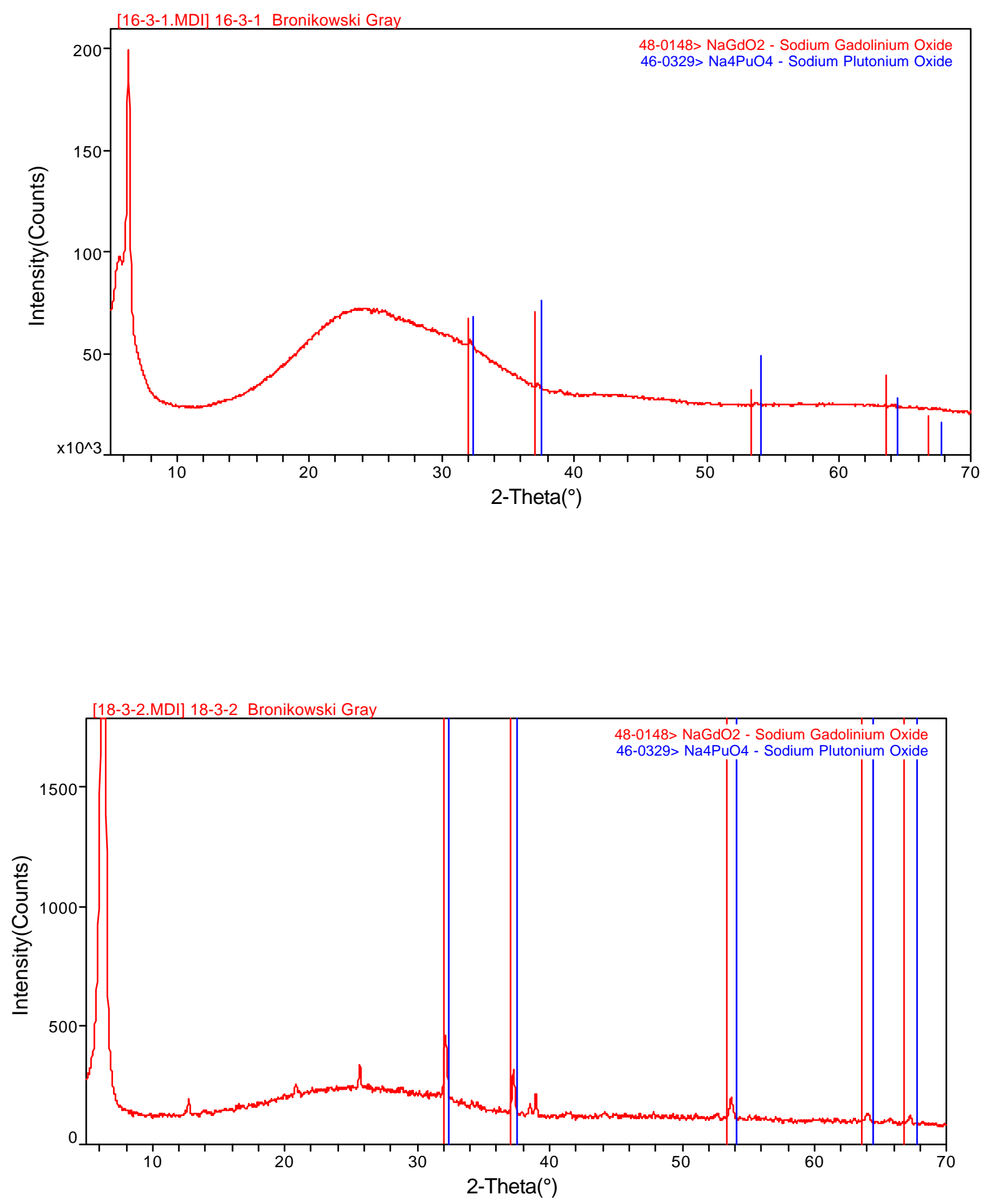
A sample of the precipitate was centrifuged and moisture was determined using a TGA. From the percentage water given off, the hydrogen to $\mathrm{Pu}$ ratio was determined to be about 130:1.

Since no negatives were identified, NMMD started to develop a baseline flowsheet and supporting safety documentation. From this baseline, a test plan was developed for precipitation studies of $\mathrm{Gd} / \mathrm{Pu}$ at a nominal ratio of 1:1.

\section{Figure 3 SEM of Gd/Pu Precipitate}

SEM of Gd/Pu Precipitate

1000X Magnification

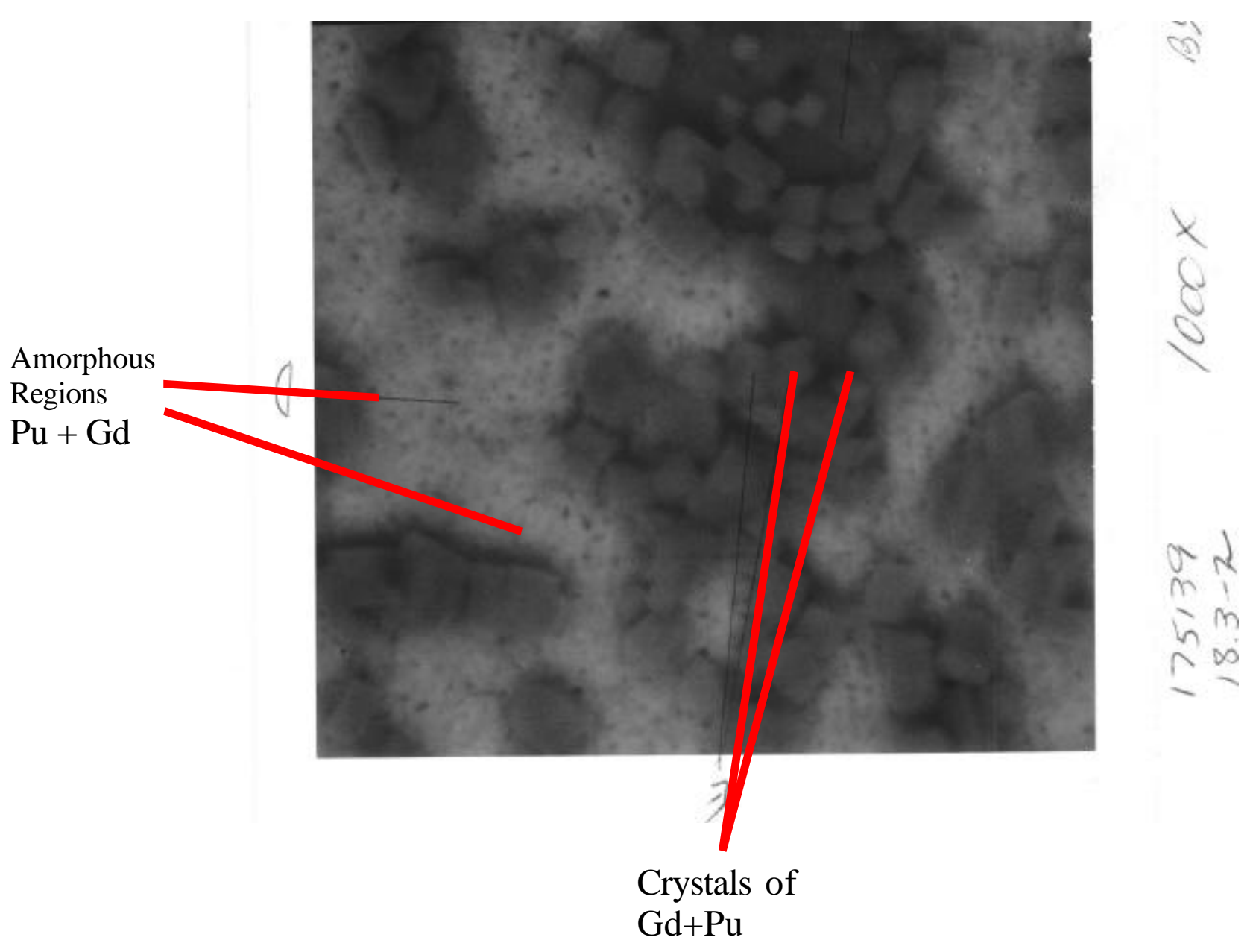




\section{Baseline Process Experiments}

\section{Neutralization Experiments:}

Five bulk neutralization experiments were run. Three experiments were run with 18.3 solution, one with 16.3 solution, and one with 12.1 solution. A change in plans resulted in the addition of 12.1 solution as one of the primary candidates for disposition. NMMD now plans to stop processing 12.1 through $\mathrm{H}-\mathrm{B}$ Line and process 16.3 instead. Tank 16.3 will not be discarded at this point. The Gd solution was made up from a $\mathrm{Gd}\left(\mathrm{NO}_{3}\right)_{3} \bullet 6 \mathrm{H}_{2} \mathrm{O}$ sample from the lot that will be used when neutralizing in H-Canyon. The actual precipitation process was carried out using the proposed H-Canyon flow sheet supplied by NMMD Engineering (see Appendix 1) with only a small amount of additional water and $\mathrm{NaOH}$ to get to a $1 \mathrm{~g} / \mathrm{L}$ final $\mathrm{Pu}$ concentration. A range of final $\mathrm{Gd}$ to $\mathrm{Pu}$ ratios run in these experiments was chosen to encompass possible operating conditions below $\mathrm{k}_{\text {eff }}=$ 0.95 as listed in Table 3. The test plan is shown in Appendix 4.

\section{Table 3 Final Weight Ratio of Neutralization Experiments}

\begin{tabular}{l|l}
\hline Experiment & $\begin{array}{l}\text { Gd:Pu } \\
\text { ratio }(\mathbf{w t})\end{array}$ \\
\hline 18.3 solution & $0.5: 1.0$ \\
18.3 solution & $1.0: 1.0$ \\
18.3 solution & $1.5: 1.0$ \\
16.3 solution & $1.0: 1.0$ \\
12.1 solution & $2.0: 1.0$ \\
\hline
\end{tabular}

A small amount of solution at 1.5:1.0 Gd:Pu was made up and left to sit for the duration of the experiment to check stability (solubility) of the mixed solution. Previous criticality work suggests that solubility will not be a problem with simple $\mathrm{Pu}, \mathrm{Gd}$, and $\mathrm{HNO}_{3}$ solutions ${ }^{6}$. The $\mathrm{Gd} / \mathrm{Pu}$ case is unlike the $2 \mathrm{BP}$ solution case where the tested $\mathrm{Pu}^{3+}$ in solution oxidized to $\mathrm{Pu}^{4+}$ after a few weeks. However, the test was run, as the real 18.3 solution contains both B and U. Additionally, the 18.3 and 12.1 solutions were analyzed for $\mathrm{Pu}, \mathrm{B}, \mathrm{Fe}, \mathrm{Mn}$, and acid concentration.

The fundamental experiment was run by adding the needed amount of a 30 wt\% $\mathrm{Gd}\left(\mathrm{NO}_{3}\right)_{3} \bullet 6 \mathrm{H}_{2} \mathrm{O}$ solution to a beaker containing $30 \mathrm{ml}$ of the tank solution to obtain the $\mathrm{Pu}: \mathrm{Gd}$ ratio needed when neutralized. $50 \%$ wt $\mathrm{NaOH}$ was then added until the concentration reached $>1.2 \mathrm{M}$ in $\mathrm{OH}^{-}$. The temperature was kept under $50^{\circ} \mathrm{C}$ during addition to approximate the plant neutralization process. Process water was added as needed to allow the solution to be pumped or to meet the waste acceptance criteria. The solution was mixed for at least two hours prior to sampling.

The solution was mixed, an aliquot taken, and centrifuged. The solids were rinsed and dissolved in concentrated $\mathrm{HNO}_{3}$. The rinse solution was matched in concentration to the 
$\mathrm{NO}_{3}{ }^{-}$and $\mathrm{NaOH}$ concentration of the final neutralized solution. Then both the dissolved solids solution and supernate were sent for radscreen ( $\mathrm{Pu}$ conc.), gamma scan (Am correction), and ICPES (B, Gd, and U conc.) analyses

The solutions were allowed to sit for a week, and then the supernate from each solution was sampled. The supernate and mixed densities were determined by specific weights. This measurement allowed an estimate of the sludge density. The solution was mixed, and again an aliquot was removed and centrifuged, and the solids were submitted for analyses. The analyses consisted of radscreens, gamma scans, and ICPES for the supernate and dissolved solids. Additionally, some solids were submitted for XRD and SEM analyses.

Three 18.3 and one 16.3 solutions were mixed. This solution was analyzed for particle size distribution using laser scattering. For dilution to the solution volume needed for the test, $150 \mathrm{ml}$ of a $1.2 \mathrm{M} \mathrm{NaOH}$ solution with the expected $\left[\mathrm{NO}_{3}{ }^{-}\right]$was used.

The TGA was run on the $\mathrm{Gd} / \mathrm{Pu}$ solids and the $\mathrm{Gd} / \mathrm{Pu}$ solids in the simulated waste to determine the weight of water that is contained in the dry sludge. The weight percent of water is needed by WSMS for criticality calculations. As done previously in the scoping tests, the solids were centrifuged and the supernate liquid was decanted prior to running the TGA.

\section{pH Tests}

The first $\mathrm{pH}$ series of tests used a simulated $\mathrm{H}$-Canyon $\mathrm{Pu}$ solution. The composition of the simulated $\mathrm{H}-\mathrm{Canyon}$ solution was five moles $\mathrm{HNO}_{3}$ containing 0.03 grams $\mathrm{U} / \mathrm{L}, 3.0$ grams $\mathrm{Pu} / \mathrm{L}$ and 4.0 grams B/L. Sufficient $\mathrm{Gd}$ was added to the $30 \mathrm{ml}$ batches of the simulated solutions to produce a 1:1 Gd:Pu ratio in each solution.

To evaluate the behavior of $\mathrm{Gd}$ and $\mathrm{Pu}$ during the neutralization studies, each of the three solutions was adjusted to a different $\mathrm{pH}$ by slowly adding a $50 \% \mathrm{NaOH}$ solution. Slow addition of the 50\% solution was required maintain solution temperatures below $50{ }^{\circ} \mathrm{C}$ (the $\mathrm{H}$-Canyon standard). The adjusted $\mathrm{pH}$ values of the three solutions were 3,7 , and $>14$. After the solution and precipitate samples were taken from the three different $\mathrm{pH}$ solutions, additional caustic solution was added to increase the final $\mathrm{pH}$ in all solutions to $>14$. Figure 5 shows the calculated solubility of $\mathrm{Gd}: \mathrm{Pu}$ vs. pH.. 
Figure 4 Precipitate Appearance vs. pH

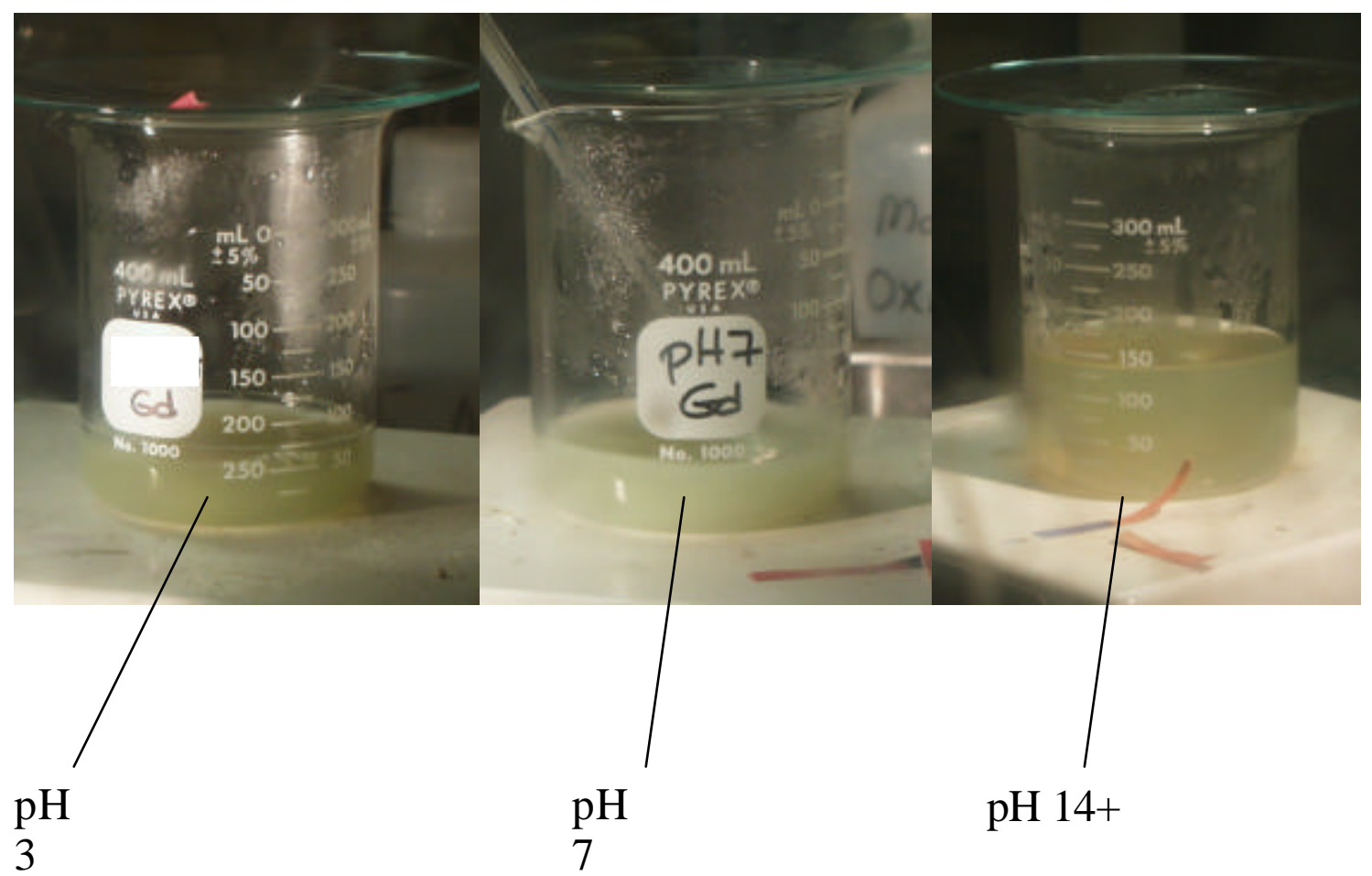

The solutions were analyzed to determine the solubility of $\mathrm{Gd}$ and $\mathrm{Pu}$ at the intermediate $\mathrm{pH}$ and after extended storage at $>\mathrm{pH} 14$. Solubility results from analyses of the supernate are shown in Table 4.

Table 4 Solubility of Pu and Gd vs. pH

\begin{tabular}{|l|l|l|}
\hline Sample & Gd Soluble (\%) & Pu Soluble (\%) \\
\hline End of Titration $(\mathrm{pH} 3)$ & $\sim 95$ & 5.1 \\
\hline After 7 Days $(\mathrm{pH}>14)$ & $<0.5$ & $<0.1$ \\
\hline After 25 Days $(\mathrm{pH}>14)$ & $<0.05$ & $<0.001$ \\
\hline End of Titration $(\mathrm{pH} 7)$ & 1.5 & 1.1 \\
\hline After 7 Days $(\mathrm{pH}>14)$ & $<0.3$ & $<1.0$ \\
\hline After 25 Days $(\mathrm{pH}>14)$ & $<0.03$ & $<0.1$ \\
\hline End of Titration $(\mathrm{pH}>14)$ & $<1.0$ & $<0.1$ \\
\hline After 7 Days $(\mathrm{pH}>14)$ & $<0.2$ & $<0.05$ \\
\hline After 25 Days $(\mathrm{pH}>14)$ & $<0.1$ & $<0.005$ \\
\hline
\end{tabular}

Solid samples were taken from each of the different $\mathrm{pH}$ solutions when the initial caustic addition was completed. Analyses of the solids by SEM confirmed that all Pu was intimately mixed with gadolinium and indicated there were no Pu particles that did not contain Gd. In addition, no free $\mathrm{Gd}$ was detected. Due to the amorphous nature of the solids, XRD scans of the solids could not identify any specific Gd-Pu compounds. 
Some of the remaining solids were dissolved to determine the $\mathrm{Gd}: \mathrm{Pu}$ ratio in the precipitate. These Gd:Pu solids are shown in Table 5 as a function of solution $\mathrm{pH}$. Each of the experiments was designed at $\mathrm{Gd}: \mathrm{Pu}$ ratios of $1: 1$. The data in Table 8 confirms that only at $\mathrm{pH} 3$ most of the Gd remains in solution. Another series was run at a $\mathrm{Gd}: \mathrm{Pu}$ ratio of 1.5:1. The ratio of the $\mathrm{Pu}: \mathrm{Gd}$ in the precipitate is shown in Figure 5.

Table 5 Gd:Pu Ratios in Precipitates vs. pH

\begin{tabular}{|l|l|l|l|}
\hline Sample & Gd Conc $(\mathrm{ppm})$ & Pu Conc, $(\mathrm{dpm} / \mathrm{ml})$ & $\mathrm{Gd}: \mathrm{Pu}$ \\
\hline $\mathrm{pH} 3$ & 17.4 & $4.1 \times 10^{7}$ & $1: 20$ \\
\hline $\mathrm{pH} 7$ & 318 & $5.3 \times 10^{7}$ & $1: 1$ \\
\hline $\mathrm{pH}>14$ & 365 & $6.5 \times 10^{7}$ & $1: 1$ \\
\hline $\begin{array}{l}\mathrm{pH}>14 \text { 2BP } \\
\text { from F-Canyon }\end{array}$ & 617 & $9.1 \times 10^{7}$ & $1: 1$ \\
\hline
\end{tabular}

The second series of $\mathrm{Gd}-\mathrm{Pu}$ precipitation studies was conducted with actual $\mathrm{Pu}$ solutions taken from H-Canyon tanks 18.3 and 16.3. In this series, the 18.3 solution was used with $\mathrm{Gd}: \mathrm{Pu}$ ratios from $0.5: 1$ to $1.5: 1$. Sufficient $\mathrm{Gd}$ was added to the 16.3 solution to attain $\mathrm{Gd}: \mathrm{Pu}$ ratios of $1: 1$. All four solutions were adjusted with $50 \%$ $\mathrm{NaOH}$ to have $\mathrm{pH}>14$.

\section{Figure 5 Gd:Pu Ratio in the Precipitate}

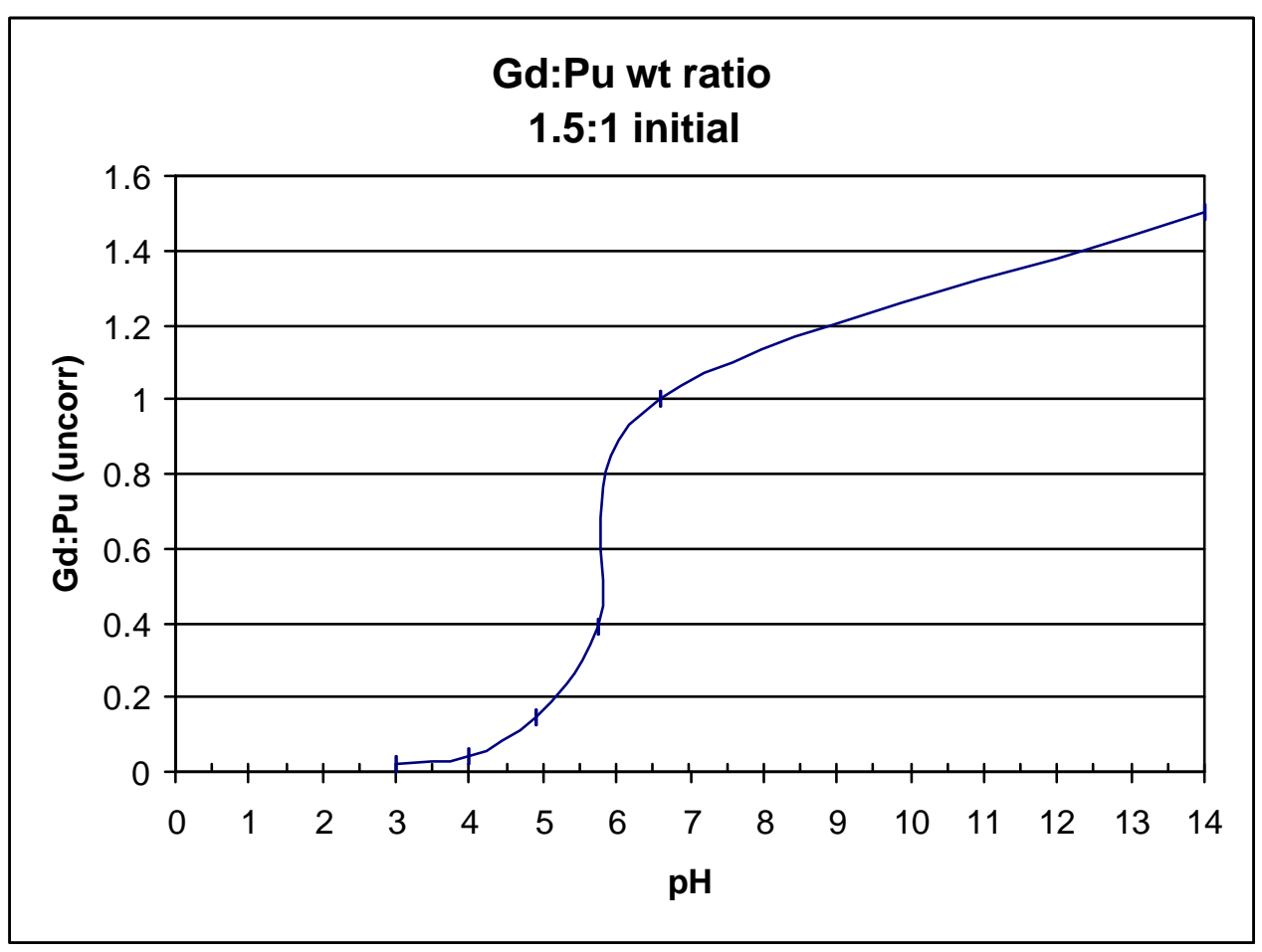


At the end of the $\mathrm{NaOH}$ addition, both solution and solid samples were taken. The solutions were analyzed for $\mathrm{Gd}$ and $\mathrm{Pu}$ to determine remaining concentrations of $\mathrm{Gd}$ and $\mathrm{Pu}$ left in solution after the caustic addition. The solids were analyzed by SEM and XRD to determine particle size characteristics and elemental structure of the precipitate. TGA was run to determine moisture content in the precipitate. All results from the SEM reconfirmed that $\mathrm{Pu}$ and $\mathrm{Gd}$ remain well mixed in the precipitate. The XRD showed little crystal structure.

The amount of $\mathrm{Pu}$ and $\mathrm{Gd}$ found in solution at the end of the run, and after a six day storage period, are shown in Table 6.

\section{Table 6 Pu and Gd Solubilities in pH >14 Solutions}

\begin{tabular}{|l|l|l|}
\hline Sample & Gd Solubility (wt.\%) & Pu Solubility (wt.\%) \\
\hline Tank 18.3 0.5:1 Gd:Pu & - & - \\
\hline End of Titration & 0.13 & 0.17 \\
\hline After 6 Days & 0.20 & 0.50 \\
\hline Tank 18.3 1:1 Gd:Pu & - & - \\
\hline End of Titration & 0.18 & 0.11 \\
\hline After 6 Days & 0.35 & 0.74 \\
\hline Tank 18.3 1.5:1 Gd:Pu & - & - \\
\hline End of Titration & 0.63 & 0.8 \\
\hline After 6 Days & 0.32 & 0.38 \\
\hline Tank 16.3 1:1 Gd:Pu & - & - \\
\hline End of Titration & 0.83 & 0.15 \\
\hline After 6 Days & 0.18 & 0.35 \\
\hline
\end{tabular}

Some of the solids sampled after six days were re-dissolved in $\mathrm{HNO}_{3}$ to determine the $\mathrm{Gd}: \mathrm{Pu}$ ratio in the precipitates from Tanks 18.3 and 16.3. These solid samples dissolved almost instantaneously in the $\mathrm{HNO}_{3}$ solution. The ability to dissolve some of the $\mathrm{Gd}-\mathrm{Pu}$ solids in acid solution was shown in subsequent SRAT (DWPF processing -Sludge Receiving and Adjustment Tank) tests, reported in a subsequent report ${ }^{7}$. The results from dissolution of the Gd-Pu are shown in Table 7. These data confirm good correlation between the calculated ratios and the ratios determined by re-dissolving in $\mathrm{HNO}_{3}$ and measuring the resultant solution.

Table 7 Gadolinium to Plutonium Ratios in Re-dissolved Solids

\begin{tabular}{|l|l|l|l|}
\hline Sample @Gd:Pu & Gd conc. $(\mathbf{m g})$ & Pu conc. $(\mathbf{m g})$ & Gd:Pu Ratio \\
\hline Tank 18.3-1 @ 0.5:1 & 0.7 & 1.13 & 0.62 \\
\hline Tank 18.3-2 @ 1.:1 & 1.145 & 1.13 & 1.01 \\
\hline Tank 18.3-3 @ 1.5:1 & 2.775 & 1.91 & 1.45 \\
\hline Tank 16.3 @ 1:1 & 0.342 & 0.35 & 0.97 \\
\hline
\end{tabular}




\section{Moisture Measurements}

To ensure the $\mathrm{Pu}$ is protected with adequate neutron poison (i.e., $\mathrm{Gd}$ ) in the transfer to the tank farm, a panel of experts from HLWD, DWPF, NMMD, WSMS, and SRTC determined that a "worst case" would be a centrifuged sample. This condition was selected because there is no heat to drive off water in the transfer line or pump tank in HLW, and air drying is extremely slow (10 plus days to lose $25 \%$ of volume at $\sim 50^{\circ} \mathrm{C}$ ). Samples of the precipitate slurry were centrifuged for five minutes in a Clay-Adams compact centrifuge that generates $\sim 1000$ G's. Approximately $25 \mathrm{mg}$ of the centrifuged precipitate was then run on the TGA to determine the amount of residual moisture present after centrifuging. The material from the centrifuge tube was sticky, much like paste. The temperature was ramped up to $500^{\circ} \mathrm{C}$ and the differential weight was calculated as water (Appendix 7). Results showed that the sample was $~ 80 \%$ water, which translated into the following atom ratio: for each $\mathrm{Pu}$ atom, 1.5 gadolinium atoms and 75.6 $\mathrm{H}^{\text {atoms. }}{ }^{8}$ Since the $\mathrm{NCSE}^{9}$ assumed $30 \mathrm{H}$ atoms were present, this result shows the NCSE is conservative.

\section{$\underline{\text { Precipitate Moisture in H-Canyon Tank }}$}

Because only part of the $\mathrm{Gd}$ precipitates when the $\mathrm{Pu}$ precipitates at $\mathrm{pH} 3$, an experiment was added to determine the amount of water associated with the $\mathrm{Pu}$ precipitate. NMMD requested an additional test to measure the settling rate of the $\mathrm{Gd} / \mathrm{Pu}$ precipitate at $\mathrm{pH}$ 3. Samples of 18.3 with $1: 1$ and $1.5: 1 \mathrm{Gd}: \mathrm{Pu}$ ratios were neutralized to $\mathrm{pH} 4$ and 4.5 and allowed to settle in a graduated cylinder for several days. The settling curve is shown in Figure 6. The thickness of the settled layer was measured and the apparent density was then calculated. The resultant precipitate was then force dried by heating (below $90^{\circ} \mathrm{C}$ ) and blowing air over the sample. The amount of water and the $\mathrm{H}: \mathrm{Pu}$ ratio were calculated.

The $\mathrm{H}: \mathrm{Pu}$ ratios are shown on a plot of the effect of $\mathrm{H}$ on the safe $\mathrm{Gd}: \mathrm{Pu}$ ratio in Figure 7. From table 5 the washed precipitate at $\mathrm{pH} 3$ had a solid $\mathrm{Gd}: \mathrm{Pu}$ ratio of 0.05. This condition is represented by the upper line through the curve in Figure 7. Washing the precipitate with distilled water as in the $1.5: 1 \mathrm{Gd}: \mathrm{Pu}$ titration case shown in Figure 5 resulted in the lower line in Figure 7. This results in a very conservative number, because no mechanism for washing the precipitate could be postulated. The H:Pu ratio (atom ratio) was then calculated and found to be $>1900$ for $1: 1 \mathrm{Gd}: \mathrm{Pu}$ and $>2500$ for $1.5: 1 \mathrm{Gd}: \mathrm{Pu}$. These ratios are represented by the vertical lines through the curve in Figure 7. The intersected area bounds the area of the $\mathrm{Pu}$ precipitation at the lower $\mathrm{pH}$. 
Figure 6 Settling Time vs. Volume

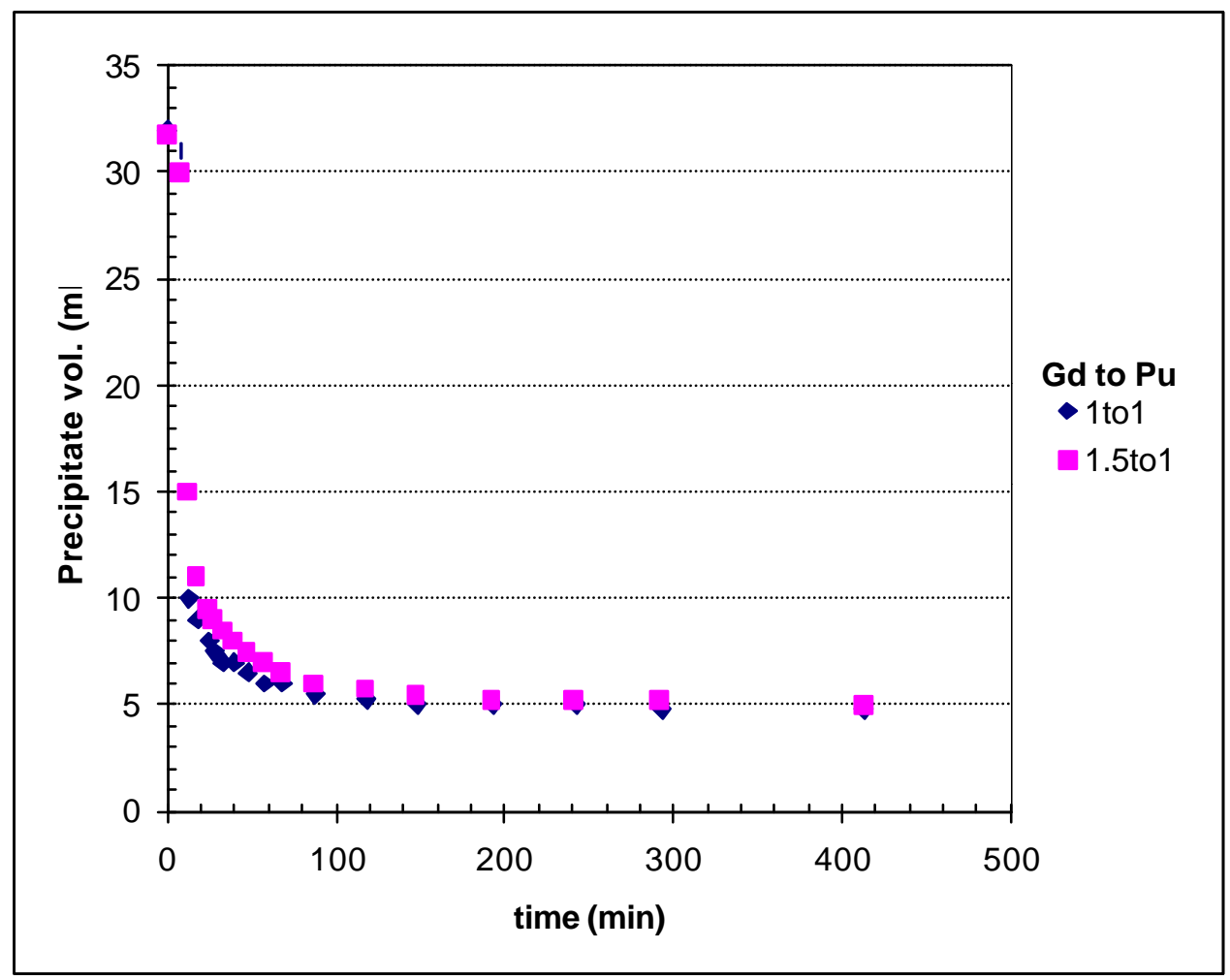

Table 8 Apparent Densities

\begin{tabular}{|l|l|l|l|}
\hline $\begin{array}{l}\text { Canyon } \\
\text { Tank No. }\end{array}$ & $\begin{array}{l}\text { Supernate } \\
\text { Sp. G. }\end{array}$ & $\begin{array}{l}\text { Mixed } \\
\text { Sp. G. }\end{array}$ & $\begin{array}{l}\text { Sludge } \\
\text { density } \\
\text { Vol. est. } \\
1.423\end{array}$ \\
$18.3-1$ & 1.195 & 1.241 & 1.505 \\
$18.3-2$ & 1.190 & 1.253 & 1.405 \\
$18.3-3$ & 1.225 & 1.279 & 1.332 \\
$16.3-1$ & 1.231 & 1.287 & \\
\hline
\end{tabular}


Figure 7 Effect of Hydrogen on Safe Gd:Pu

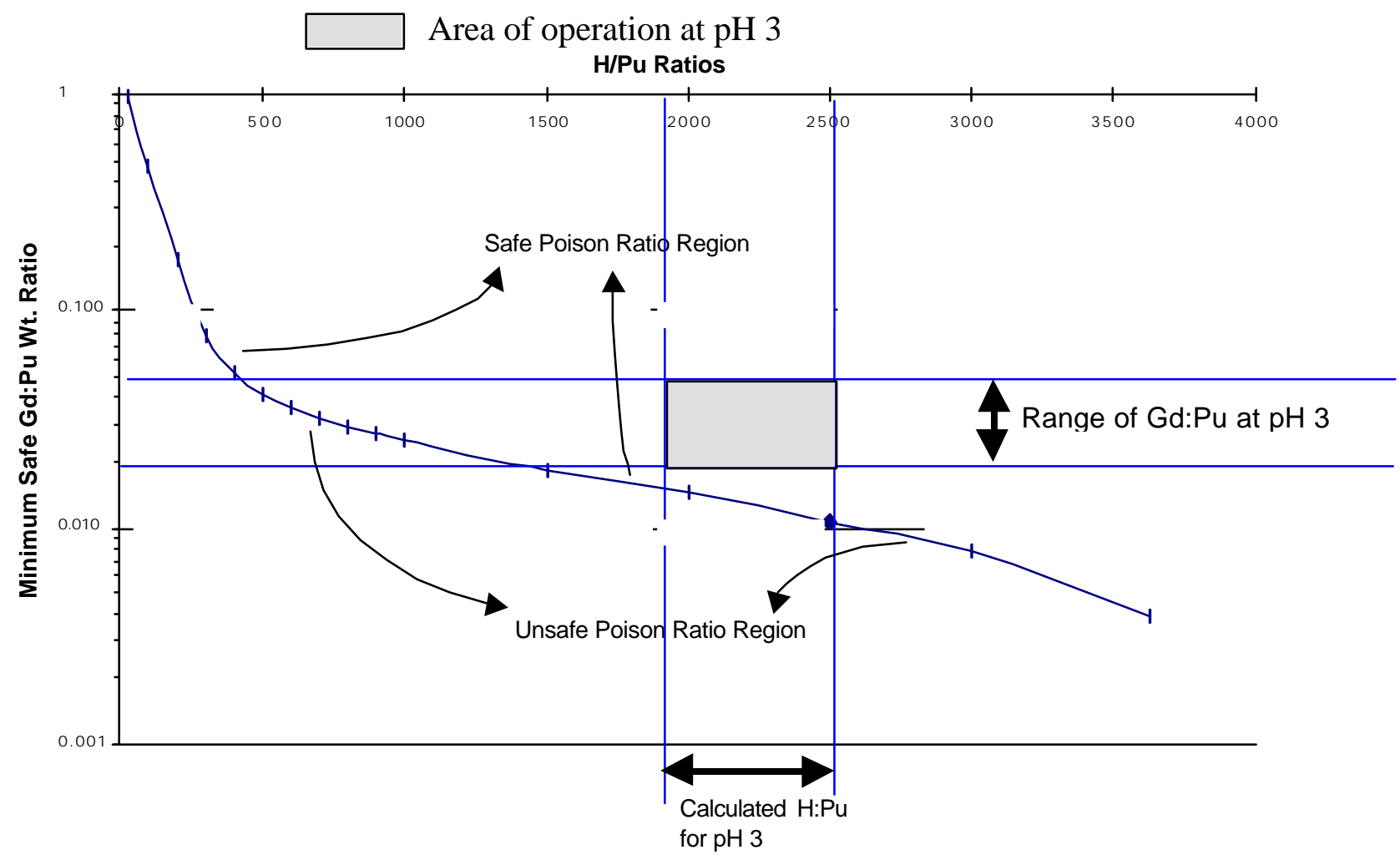




\section{Particle size Measurement}

The precipitates from Tanks 16.3 and 18.3 were combined and submitted for particle size distribution by laser scattering. The sample that was submitted was allowed to settle for 3 days and significant agglomeration occurred (Figure 8). The sample was then mixed to re-suspend the particles, and a second measurement was made (Figure 9). The particles in the settled material had a bimodal distribution. Re-suspending the material resulted in a single particle size distribution, skewed toward very small particles.

\section{Figure 8 Agglomerated Particle Size in Microns}

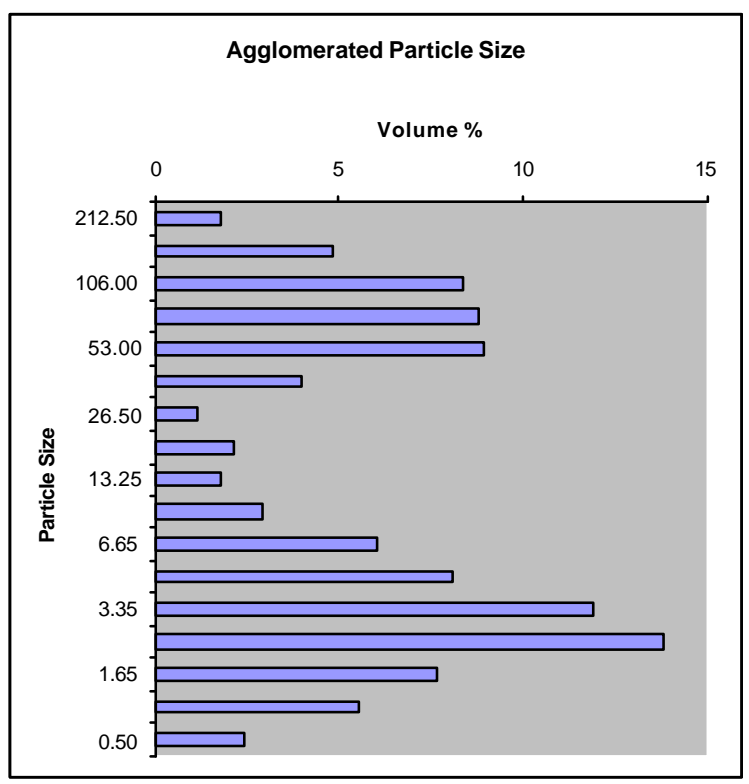

Figure 9 Agitated Particle Size in Microns

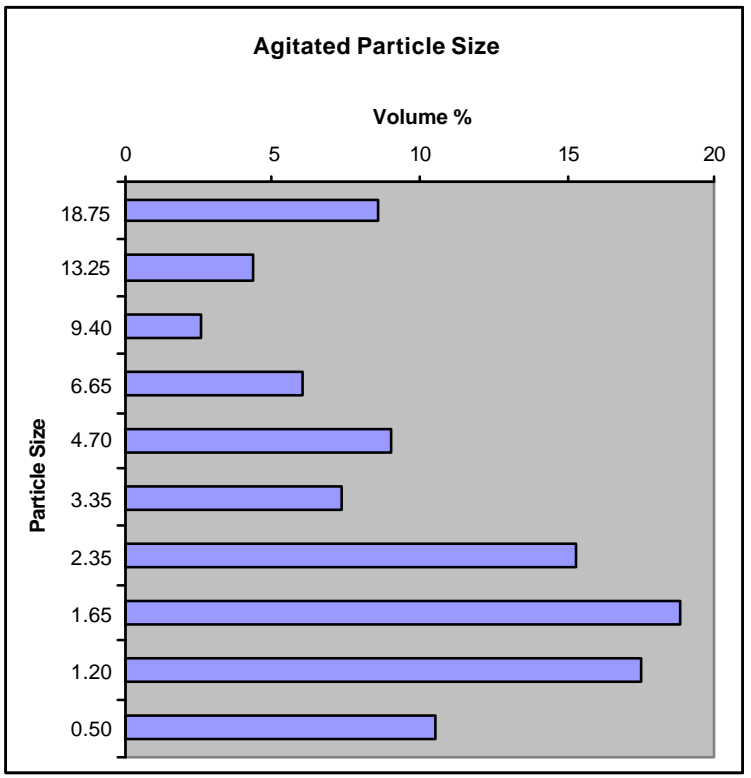


The precipitates were dried and prepared for XRD. The results showed an amorphous material, with some crystalline structure. $\mathrm{Gd}$ and $\mathrm{Pu}$ were present in all samples. The crystals were probably some form of $\mathrm{NaGdPuO}_{\mathrm{x}}$, which was not identified. The amorphous material was probably a mixture of $\mathrm{Pu}(\mathrm{OH})_{4}$ and $\mathrm{Gd}(\mathrm{OH})_{3}$, although the XRD was not definitive.

\section{Sludge Washing and SRAT tests:}

The new Pu/Gd sludge was made up for the SRAT tests. The Gd:Pu ratio was 1.4:1.0 and $100 \mathrm{ml}$ of 18.3 was used. The $100 \mathrm{ml}$ sample of 18.3 was the largest amount of $\mathrm{Pu}$ solution neutralized. No difference in the precipitation process or precipitate was noted. This new precipitate was added to simulated sludge obtained from the waste immobilization group to produce the final expected concentration of the waste.

As in the real process, inhibited water $(0.01 \mathrm{M} \mathrm{NaOH})$ was used to wash the sludge. The wash solution was tested for $\mathrm{Gd}, \mathrm{B}, \mathrm{Fe}$, and $\mathrm{Pu}$ concentration. The sludge was then heated to $93^{\circ} \mathrm{C}$, acidified to $\sim \mathrm{pH} 5.5$ and boiled at $103^{\circ} \mathrm{C}$ for 12 hours. The sludge was sampled for analysis. The sludge was again run through the SRAT cycle above but at a lower $\mathrm{pH}$ of $\sim 3$. These results will be discussed in separate report ${ }^{7}$.

\section{Conclusions}

Precipitation of $\mathrm{Pu}$ from a $\mathrm{HNO}_{3}$ solution with $\mathrm{NaOH}$ can be done safely using gadolinium as a neutron absorber (poison). Concerns are centered on the transient during neutralization between $\mathrm{pH} 3$, when $\mathrm{Pu}$ starts to precipitate, and $\mathrm{pH} 7$, when gadolinium precipitates. This transient will only last seconds with normal operation. Experimental work has shown that the precipitate at $\mathrm{pH} 3$ has a high water content with enough Gd to remain safe. The precipitate particle size was found to be less than 20 microns when agitated and particles were easily re-suspended with a standard laboratory stirring-bar. The material did not tend to adhere to the walls of glassware, or give any other indications that there would be a problem in transporting the precipitate to the waste tanks. Behavior during processing of the sludge batch for DWPF will be discussed in subsequent reports ${ }^{7,10}$. 


\section{Appendix}




\section{Appendix 1 Flow Sheets for Gd Addition and Neutralization}

I| $\mid$ O027E\027\&|1O1027\&k2S

POISONING PLUTONIUM WITH GADOLINIUM NITRATE AND NEUTRALIZING WITH $50 \%$ NAOH

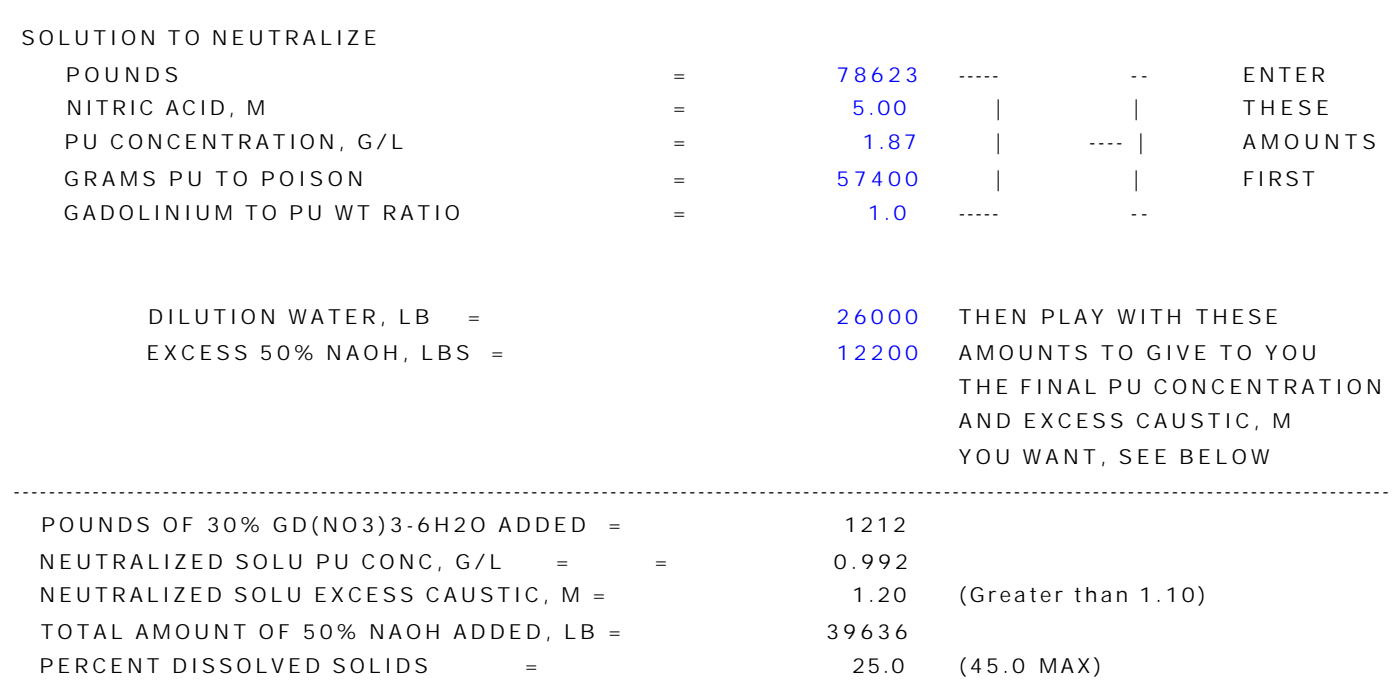

\section{POISONING FLOWSHEET}

\begin{tabular}{|c|c|c|c|c|}
\hline MATERIAL & LB & KG & LITERS & DENSITY \\
\hline SOLU TO NEUTRALIZE & 78623 & 35657 & 30695 & 1.162 \\
\hline $30 \%$ GD $\left(\mathrm{NO}_{3}\right) 3-6 \mathrm{H} 2 \mathrm{O}$ & 1212 & 549.6 & 448.8 & 1.225 \\
\hline DILUTION WATER & 26000 & & & \\
\hline TOTAL & 105835 & 47998 & 43008 & 1.116 \\
\hline \multicolumn{5}{|c|}{ NEUTRALIZING FLOWSHEET } \\
\hline MATERIAL & LB & KG & LITERS & DENSITY \\
\hline $50 \% \mathrm{NAOH}$ & 27436 & 12443 & & \\
\hline NEUTRALIZED WASTE & 133271 & 60440 & 54158 & 1.116 \\
\hline $50 \%$ NAOH EXTRA & 12200 & 5533 & 3689 & 1.5 \\
\hline $1.2 \mathrm{M} \mathrm{NAOH} \mathrm{EXCESS}$ & 142348 & 64557 & 57846 & 1.116 \\
\hline
\end{tabular}

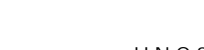
$\begin{array}{rcr}\text { MOLAR } & \text { MOLES } & \text { KG } \\ 5.00 & 153476 & 9669\end{array}$

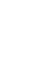




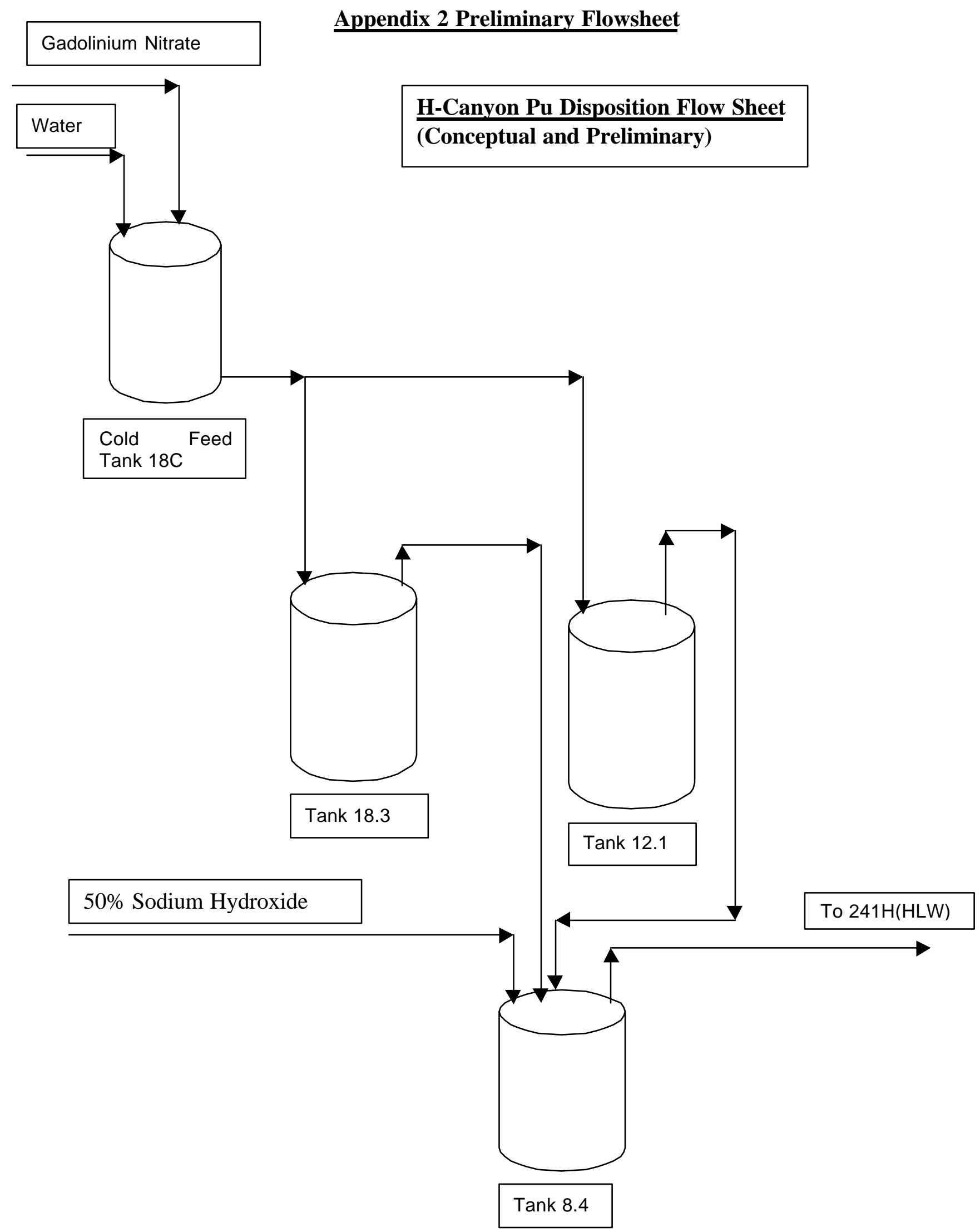




\section{Appendix 3 Scoping Studies with Mn as Poison}

Neutralization tests were run with the 64:1 and 32:1 Mn to Pu flowsheets provided by F-Canyon engineers. The normal F-Canyon neutralization procedure was followed. The $\mathrm{Pu}$ solution to be neutralized was added to a beaker along with the requisite amount of neutron poison from an acidic $\mathrm{Mn}\left(\mathrm{NO}_{3}\right)_{2}$. 50 wt. $\% \mathrm{NaOH}$ was added with agitation so that the temperature was kept below $50^{\circ} \mathrm{C}$ and the final free hydroxide concentration was $>1.2 \mathrm{M}$. Two temperature ranges were run: 1 ) between $30-40^{\circ} \mathrm{C}$ and 2) between $40-50^{\circ} \mathrm{C}$. DI water was then added and the solution was left to react for two hours prior to sampling.

Partial neutralization tests were run in the same manner as full neutralization tests except that initially only part of the $50 \mathrm{wt} \% \mathrm{NaOH}$ was used. The solutions were allowed to react for two hours and sampled. After sampling, the rest of the $\mathrm{NaOH}$ was added to get to a concentration of $>1.2 \mathrm{M}$ followed by the addition of DI water.

Sampling of each neutralization test after the two-hour reaction period was done as follows. An aliquot of the mixed solution was pulled and centrifuged. The liquid phase was split into two parts. One part was to be analyzed by ICP-ES for elements $\mathrm{Mn}, \mathrm{U}$, and $\mathrm{B}$. The other part was analyzed for its $\mathrm{Pu}$ concentration using radscreen and corrected for the Am activity using gamma scan results. The solids were washed with a $\mathrm{NaOH}$ solution of the same $\mathrm{pH}$ and $\mathrm{NO}_{3}{ }^{-}$concentration as the test solution and centrifuged. The solids were analyzed by $\mathrm{x}$-ray diffraction (XRD) to determine compounds produced and scanning electron microscopy to determine the $\mathrm{Pu}$ and $\mathrm{Mn}$ distribution.

Table $930 \mathrm{ml}$ Tests at pH 14 or Full Neutralization

\begin{tabular}{|c|c|c|c|c|c|c|}
\hline $\begin{array}{c}\mathrm{Mn}: \mathrm{Pu} \\
\text { Ratio } \\
\text { (pattern) }\end{array}$ & $\begin{array}{c}\text { 2BP Simulant } \\
(2 \mathrm{~g} / \mathrm{L} \mathrm{Pu}, 0.4 \mathrm{M} \\
\mathrm{HNO}, 0.1 \\
\mathrm{HAN})\end{array}$ & $\begin{array}{c}50 \mathrm{wt} \% \\
\mathrm{Mn}\left(\mathrm{NO}_{3}\right)_{2}\end{array}$ & $\begin{array}{c}50 \mathrm{wt} \% \\
\mathrm{NaOH}\end{array}$ & DI water & Temp. & $\begin{array}{c}\text { Total } \\
\text { volume }\end{array}$ \\
\hline $64: 1(121)$ & $30 \mathrm{ml}$ & $16.2 \mathrm{ml}$ & $22.4 \mathrm{ml}$ & $159 \mathrm{ml}$ & $25-30$ & $228 \mathrm{ml}$ \\
\hline $32: 1(111)$ & $30 \mathrm{ml}$ & $8.1 \mathrm{ml}$ & $22.4 \mathrm{ml}$ & $159 \mathrm{ml}$ & $25-30$ & $220 \mathrm{ml}$ \\
\hline $64: 1(122)$ & $30 \mathrm{ml}$ & $16.2 \mathrm{ml}$ & $22.4 \mathrm{ml}$ & $159 \mathrm{ml}$ & $40-50$ & $228 \mathrm{ml}$ \\
\hline $32: 1(112)$ & $30 \mathrm{ml}$ & $8.1 \mathrm{ml}$ & $22.4 \mathrm{ml}$ & $159 \mathrm{ml}$ & $40-50$ & $220 \mathrm{ml}$ \\
\hline
\end{tabular}

Several problems were noted with the Mn precipitation that would preclude using Mn as a neutron poison, when neutralizing more than a critical mass of $\mathrm{Pu}$. Mn use for less than a critical mass would still be acceptable ${ }^{1}$. The rheology of the neutralized product and known potential chemical changes during the aging of the product are minor problems. The separation of $\mathrm{Pu}$ from $\mathrm{Mn}$ seen below a $\mathrm{pH}$ of 5 was seen as a major problem. Possible separation mechanisms can be postulated at full neutralization to $>1.2 \mathrm{M} \mathrm{OH}^{-}$as 
seen in the SEM (figure 10) where amorphous $\mathrm{Mn}(\mathrm{OH})_{2}$, and $\mathrm{Pu}$ and $\mathrm{Mn}$ solids are formed separately.

Table 10 pH 3 Runs

\begin{tabular}{|c|c|c|c|c|c|c|}
\hline $\begin{array}{c}\mathrm{Mn}: \mathrm{Pu} \\
\text { Ratio } \\
\text { (pattern) }\end{array}$ & $\begin{array}{c}\text { 2BP Simulant } \\
(2 \mathrm{~g} / \mathrm{L} \mathrm{Pu}, 0.4 \mathrm{M} \\
\mathrm{HNO}, 0.1 \\
\mathrm{HAN})\end{array}$ & $\begin{array}{c}50 \mathrm{wt} \% \\
\mathrm{Mn}\left(\mathrm{NO}_{3}\right)_{2}\end{array}$ & $\begin{array}{c}50 \mathrm{wt} \% \\
\mathrm{NaOH}\end{array}$ & DI water & Temp. & $\begin{array}{c}\text { Total } \\
\text { volume }\end{array}$ \\
\hline $64: 1(221)$ & $30 \mathrm{ml}$ & $16.2 \mathrm{ml}$ & $\begin{array}{c}1.0 \mathrm{ml} \\
+18 \mathrm{ml}\end{array}$ & $132 \mathrm{ml}$ & $25-30$ & $\begin{array}{c}47.2 \mathrm{ml} \\
* 189 \mathrm{ml}\end{array}$ \\
\hline $32: 1(211)$ & $30 \mathrm{ml}$ & $8.1 \mathrm{ml}$ & $\begin{array}{c}1.0 \mathrm{ml} \\
+17 \mathrm{ml}\end{array}$ & $126 \mathrm{ml}$ & $25-30$ & $\begin{array}{c}39.1 \mathrm{ml} \\
* 182 \mathrm{ml}\end{array}$ \\
\hline $64: 1(222)$ & $30 \mathrm{ml}$ & $16.2 \mathrm{ml}$ & $\begin{array}{c}1.0 \mathrm{ml} \\
+18 \mathrm{ml}\end{array}$ & $132 \mathrm{ml}$ & $40-50$ & $\begin{array}{c}47.2 \mathrm{ml} \\
* 189 \mathrm{ml}\end{array}$ \\
\hline $32: 1(212)$ & $30 \mathrm{ml}$ & $8.1 \mathrm{ml}$ & $\begin{array}{c}1.0 \mathrm{ml} \\
+17 \mathrm{ml}\end{array}$ & $126 \mathrm{ml}$ & $40-50$ & $\begin{array}{c}39.1 \mathrm{ml} \\
* 182 \mathrm{ml}\end{array}$ \\
\hline
\end{tabular}

$* 8.0 \mathrm{ml}$ was sampled prior to final neutralization and water addition

\section{Table 11 Real 2BP Runs}

\begin{tabular}{|c|c|c|c|c|c|c|}
\hline $\begin{array}{c}\mathrm{Mn}: \mathrm{Pu} \\
\text { Ratio } \\
\text { (pattern) }\end{array}$ & 2BP & $\begin{array}{c}50 \mathrm{wt} \% \\
\mathrm{Mn}\left(\mathrm{NO}_{3}\right)_{2}\end{array}$ & $\begin{array}{c}50 \mathrm{wt} \% \\
\mathrm{NaOH}\end{array}$ & DI water & Temp. & $\begin{array}{c}\text { Total } \\
\text { volume }\end{array}$ \\
\hline $64: 1(\mathrm{R} 122)$ & $30 \mathrm{ml}$ & $16.2 \mathrm{ml}$ & $22.4 \mathrm{ml}$ & $159 \mathrm{ml}$ & $40-50$ & $228 \mathrm{ml}$ \\
\hline $64: 1(\mathrm{R} 221)$ & $30 \mathrm{ml}$ & $16.2 \mathrm{ml}$ & $\begin{array}{c}1.0 \mathrm{ml} \\
+18 \mathrm{ml}\end{array}$ & $* 132 \mathrm{ml}$ & $25-30$ & $\begin{array}{c}47.2 \mathrm{ml} \\
* 197 \mathrm{ml}\end{array}$ \\
\hline $\begin{array}{c}\mathrm{Gd}: \mathrm{Pu} \\
\text { Ratio } \\
\text { (pattern) }\end{array}$ & $2 \mathrm{BP}$ & $\begin{array}{c}3.7 \mathrm{~g} / \mathrm{L} \mathrm{Gd} \\
\text { in } 1.22 \mathrm{M} \\
\mathrm{HNO}_{3}\end{array}$ & $\begin{array}{c}50 \mathrm{wt} \% \\
\mathrm{NaOH}\end{array}$ & DI water & Temp. & $\begin{array}{c}\text { Total } \\
\text { volume }\end{array}$ \\
\hline $1: 1(\mathrm{R} 122)$ & $30 \mathrm{ml}$ & $16.2 \mathrm{ml}$ & $22.4 \mathrm{ml}$ & $159 \mathrm{ml}$ & $25-40$ & $228 \mathrm{ml}$ \\
\hline
\end{tabular}

* sampled after final neutralization and water addition, should have been prior to neutralization 
Figure 10 SEM of Pu \& Mn Precipitate

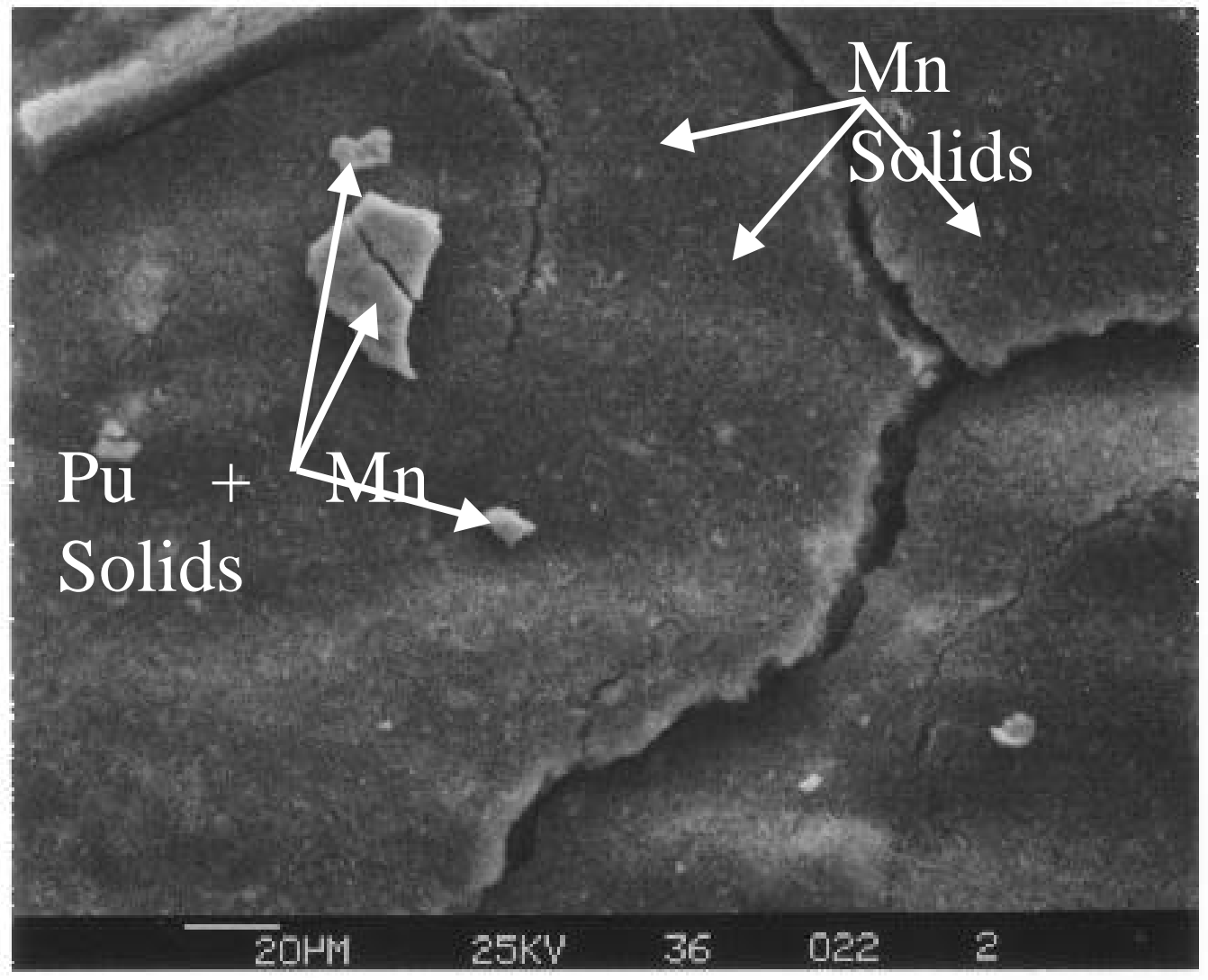




\section{$\underline{\text { Appendix } 4 \text { Test Plan for } \mathrm{Gd} / \mathrm{Pu} \text { Neutralization Tests }}$}

\begin{tabular}{|c|c|c|c|c|c|}
\hline $\begin{array}{c}\text { Gd:Pu } \\
\text { Experiment } \\
\text { of 1/30/02 }\end{array}$ & Solution & $\begin{array}{c}30 \% \\
\mathrm{Gd}_{\left(\mathrm{NO}_{3}\right)_{3}} \bullet 6 \mathrm{H} \\
{ }_{2} 0 \\
(\sim 1.236 \mathrm{~g} / \mathrm{ml})\end{array}$ & $\begin{array}{c}0.01 \mathrm{M} \\
\mathrm{HNO}_{3}\end{array}$ & $\begin{array}{c}50 \% \mathrm{wt} \\
\mathrm{NaOH} \\
(1.5 \mathrm{~g} / \mathrm{ml})\end{array}$ & $\begin{array}{c}\text { Additional } \\
\text { Process } \mathrm{H}_{2} \mathrm{O}\end{array}$ \\
\hline $0.5: 1.0$ & $30 \mathrm{ml} 18.3$ & $0.264 \mathrm{~g}$ & $11.7250 \mathrm{~g}$ & $17.5198 \mathrm{~g}$ & $2.4108 \mathrm{~g}$ \\
\hline $1.0: 1.0$ & $30 \mathrm{ml} 18.3$ & $0.535 \mathrm{~g}$ & $11.5478 \mathrm{~g}$ & $17.5689 \mathrm{~g}$ & $2.4036 \mathrm{~g}$ \\
\hline $1.5: 1.0$ & $30 \mathrm{ml} \mathrm{18.3}$ & $0.810 \mathrm{~g}$ & $11.3161 \mathrm{~g}$ & $17.6414 \mathrm{~g}$ & $2.4202 \mathrm{~g}$ \\
\hline & & & & & \\
\hline $1.0: 1.0$ & $30 \mathrm{ml} \mathrm{16.3}$ & $0.446 \mathrm{~g}$ & $5.9571 \mathrm{~g}$ & $16.5955 \mathrm{~g}$ & $0 \mathrm{~g}$ \\
\hline
\end{tabular}

Added 30ml to $125 \mathrm{ml}$ beaker, added grams Gd nitrate solution by rinsing of small vial it was in twice with the 18.3 or 16.3 solution. Added the first step of process water in the same way.

Stirring was set at $276 \mathrm{rpm}$ with 3/4"x 5/16" stir bars. $\mathrm{NaOH}$ was added slowly with a transfer pipette to attempt to keep the solution temperature below $50^{\circ} \mathrm{C}$ (highest temperature attained was $53^{\circ} \mathrm{C}$ ). The first 18.3 neutralization took 15 min due to change in stirbars. Subsequent neutralizations took $\sim 8 \mathrm{~min}$. Added rest of process water after neutralization. Let stir for 2 hours. Samples were taken after stirring.. 


\section{Appendix 5 Experimental Procedure to Determine Gd/Pu Ratio vs. pH}

\section{Titration Precipitation}

1) Made up the initial solution that would be neutralized.

2) To $20 \mathrm{ml}$ of $18.3,0.5640 \mathrm{~g}$ of a $30 \%$ wt $\mathrm{Gd}\left(\mathrm{NO}_{3}\right)_{3} \cdot \bullet 6 \mathrm{H}_{2} \mathrm{O}(\sim 0.434 \mathrm{ml}$ using sp.g. $=1.236$ ) added $7.5583 \mathrm{~g}$ of $0.01 \mathrm{M} \mathrm{HNO}_{3}$.

3) $26.5 \mathrm{ml}$ of this solution was found to weigh $30.17 \mathrm{~g}$ giving a sp.g. of 1.138 .

4) Free acid concentration was determined by titration to be $3.2 \mathrm{M}$.

Solution required $8.1 \mathrm{~g}$ or $5.3 \mathrm{ml}$. of $50 \% \mathrm{NaOH}$ to reach a $\mathrm{pH}$ of 3 as measured by a $\mathrm{pH}$ probe. At $\mathrm{pH}=3.0$ one drop of $50 \%$ caustic increases the $\mathrm{pH}$ to 6-7. Solution was acidified and a dilute $\sim 0.1 \mathrm{M} \mathrm{NaOH}$ solution was used to adjust the $\mathrm{pH}$ to $\mathrm{pH}$ of 3.0, 4.0, 4.9, 5.75, and 6.6. After adjustment to a $\mathrm{pH}$ a $3 \mathrm{ml}$ slurried sample was pulled. The samples were left overnight, and centrifuged. The solids were washed with $3 \mathrm{ml}$ of distilled water and dissolved in $1 \mathrm{ml}$ of $8 \mathrm{M} \mathrm{HNO}_{3}$. 


\section{Appendix 6 18.3 Pu/Gd Precipitates Contain Fe}

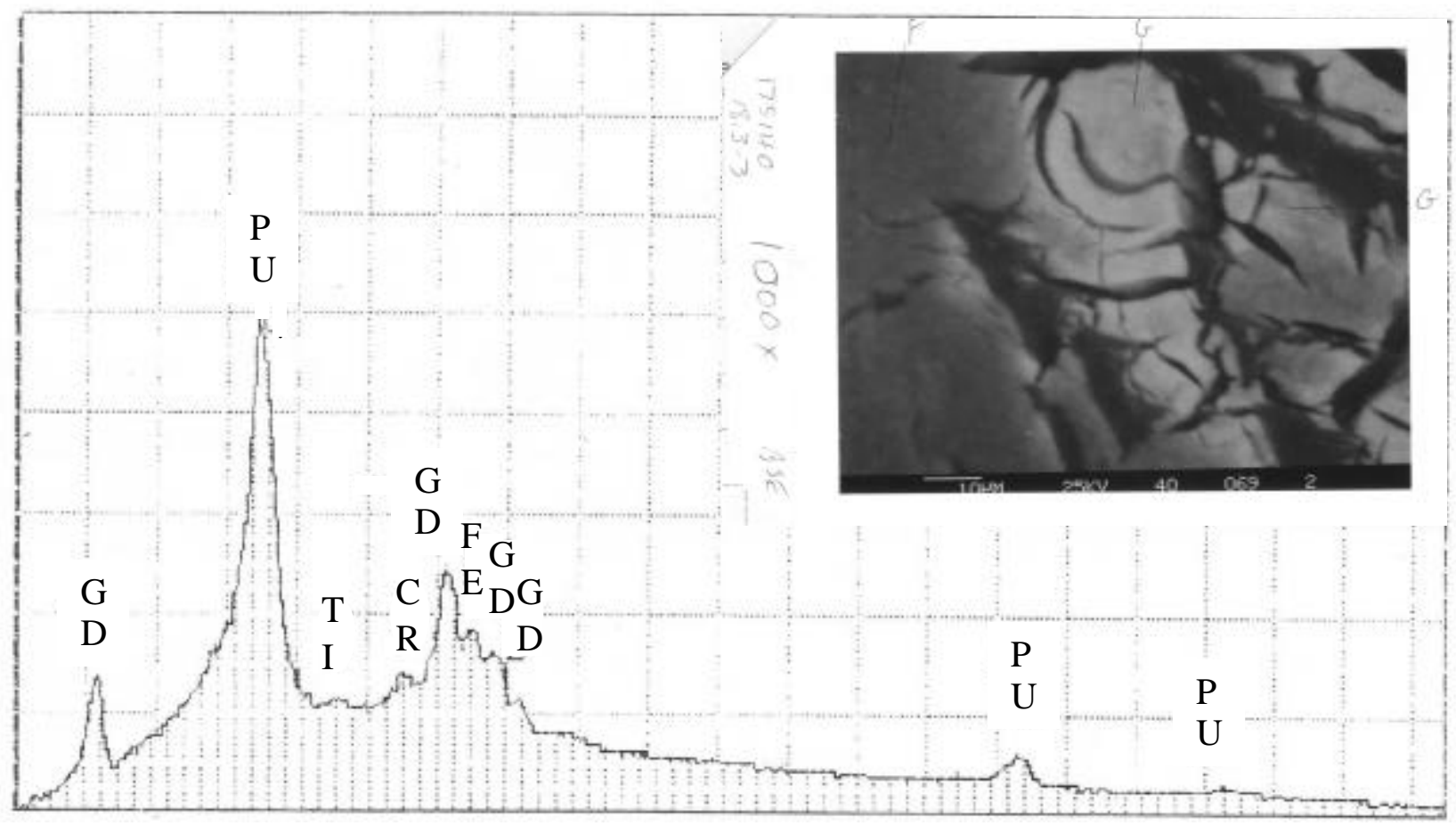

The figure above is an SEM photo and elemental analysis of solids produced by neutralizing 18.3 solution at the $1.5: 1 \mathrm{Gd}: \mathrm{Pu}$ ratio. These solids precipitated in a $30 \mathrm{ml}$ neutralization are the same as those precipitated in the $100 \mathrm{ml}$ batch for subsequent use in the simulated batch 3 sludge washing and SRAT testing. Note that the Fe that was in the initial solution precipitates in the solid along with the $\mathrm{Pu}$ and $\mathrm{Gd}$. The final $\mathrm{Gd}$ to $\mathrm{Pu}$ ratio was determined to be 1.4 to 1 since the $100 \mathrm{ml} 18.3$ sample now contained $2.0 \mathrm{~g} / \mathrm{l} \mathrm{Pu}$ and not the $1.87 \mathrm{~g} / \mathrm{l}$ it had contained in previously. The 1.4 to $1 \mathrm{Gd}: \mathrm{Pu}$ ratio is in the range (1.0-1.5) of $\mathrm{Gd}$ concentration that will be used in the process. 


\section{Appendix 7 TGA Curve To Determine Moisture}

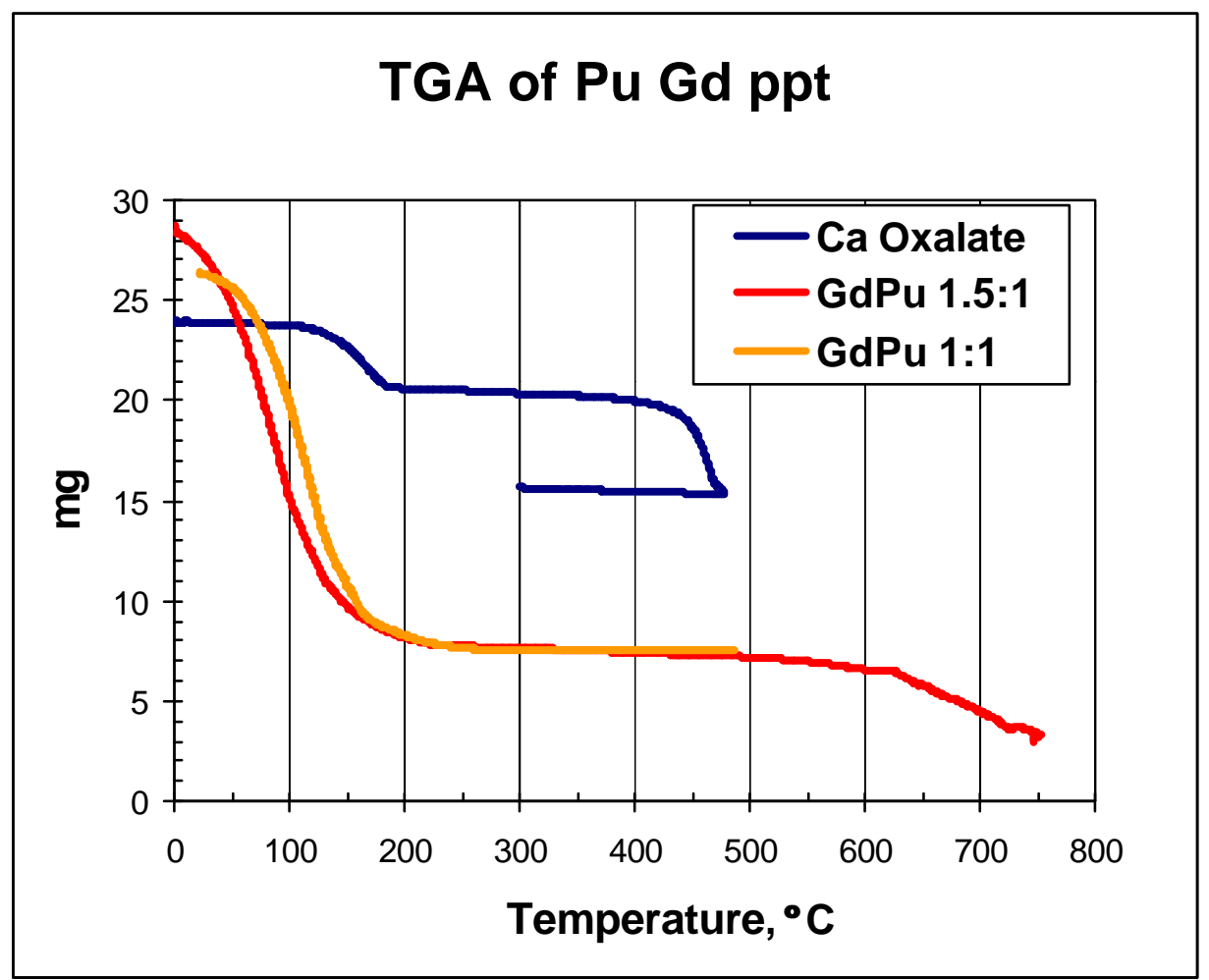

These representative TGA curves show that only water is removed upon TGA analyses. Calcium oxalate standard curve shows the expected temperature range for water of hydration loss between $150^{\circ} \mathrm{C}$ and $200^{\circ} \mathrm{C}$. Using the weight loss of the initial solid to that at $250^{\circ} \mathrm{C}$ allowed calculation of the $\mathrm{H}$ to $\mathrm{Pu}$ atom ratio given in the text and the $\mathrm{Pu}: \mathrm{Gd}: \mathrm{H}$ atom ratio. ${ }^{7}$ 


\section{Appendix 8 Water Estimates of H-Canyon Precipitate}

For this determination $20 \mathrm{ml}$ samples of 18.3 were neutralized to $1: 1$ and $1.5: 1 \mathrm{Gd}$ to $\mathrm{Pu}$ ratio and a $\mathrm{pH}$ of 3 (actual $\mathrm{pH}$ attained was 4.5 and 5.0) and allowed to settle in graduated cylinders. Tank 18.3 samples have varied between 1.87 and $2.0 \mathrm{~g} / \mathrm{l} \mathrm{Pu}$ due to evaporation. Using the $2 \mathrm{~g} / \mathrm{l}$ concentration of the sample the $\mathrm{Gd}$ to Pu ratio is $0.94: 1$ and 1.4:1. After settling, the supernate was removed from the graduated cylinders to $1 \mathrm{ml}$ and $0.5 \mathrm{ml}$ above the solids in the 1:1 and 1.4:1 case respectively. The solids were dried in the cylinders under low heat and vacuum. A $10 \mathrm{ml}$ sample of each supernate was also dried to determine the water content of these supernates. The weight of the water in the solids was calculated from the difference of the weight of the original precipitate and the dried precipitate minus the weight of the water associated with the $1 \mathrm{ml}$ and $0.5 \mathrm{ml}$ of supernate. To be conservative for estimating the water we assumed $2 \mathrm{~g} / \mathrm{L} \mathrm{Pu}$ in 18.3 and not having the solids completely dry. Still visible water on the cylinder for 1 to 1 case. We can say that $\mathrm{H}$ to $\mathrm{Pu}$ ratio in the settled (71 hrs or 3days) $\mathrm{Gd} / \mathrm{Pu}$ precipitates is:

0.94:1.0, $\mathrm{pH}=4.5$, settled to $12.5 \%, \mathrm{H}: \mathrm{Pu}>1900: 1$

1.4:1.0, $\mathrm{pH}=5.0$, solids settled to $15.7 \%, \mathrm{H}: \mathrm{Pu}>2500: 1$

The $\mathrm{H}: \mathrm{Pu}$ ratio would be higher if $1.87 \mathrm{~g} / \mathrm{L}$ was used.

As of $4 / 25 / 02$

\begin{tabular}{|l|l|l|l|l|l|l|}
\hline $\mathrm{Gd}: \mathrm{Pu}$ & $\begin{array}{l}\text { Initial } \\
\text { Mass }\end{array}$ & Supernate & $\begin{array}{l}\text { Final } \\
\text { Mass }\end{array}$ & $\begin{array}{l}\text { Water } \\
\text { Mass }\end{array}$ & $\begin{array}{l}\text { Water in } \\
\text { Supernate }\end{array}$ & $\begin{array}{l}\mathrm{H} \text { to } \mathrm{Pu} \\
\text { (Atom) }\end{array}$ \\
\hline $0.94: 1.0$ & $98.2568 \mathrm{~g}$ & $1.0 \mathrm{ml}$ & 94.4362 & $3.8206 \mathrm{~g}$ & $0.8845 \mathrm{~g}$ & $1949: 1$ \\
\hline $1.4: 1.0$ & 98.2641 & $0.5 \mathrm{ml}$ & 93.8850 & $4.3791 \mathrm{~g}$ & $0.4429 \mathrm{~g}$ & $2613: 1$ \\
\hline
\end{tabular}




\section{Appendix 9 Neutralization Curves}

Estimated based on $8 \mathrm{~kg}$ of $\mathrm{Pu}$ neutralized with $50 \% \mathrm{NaOH}$ at $20 \mathrm{lbs} / \mathrm{min}$ 1.5:1 $\mathrm{Gd}: \mathrm{Pu}$

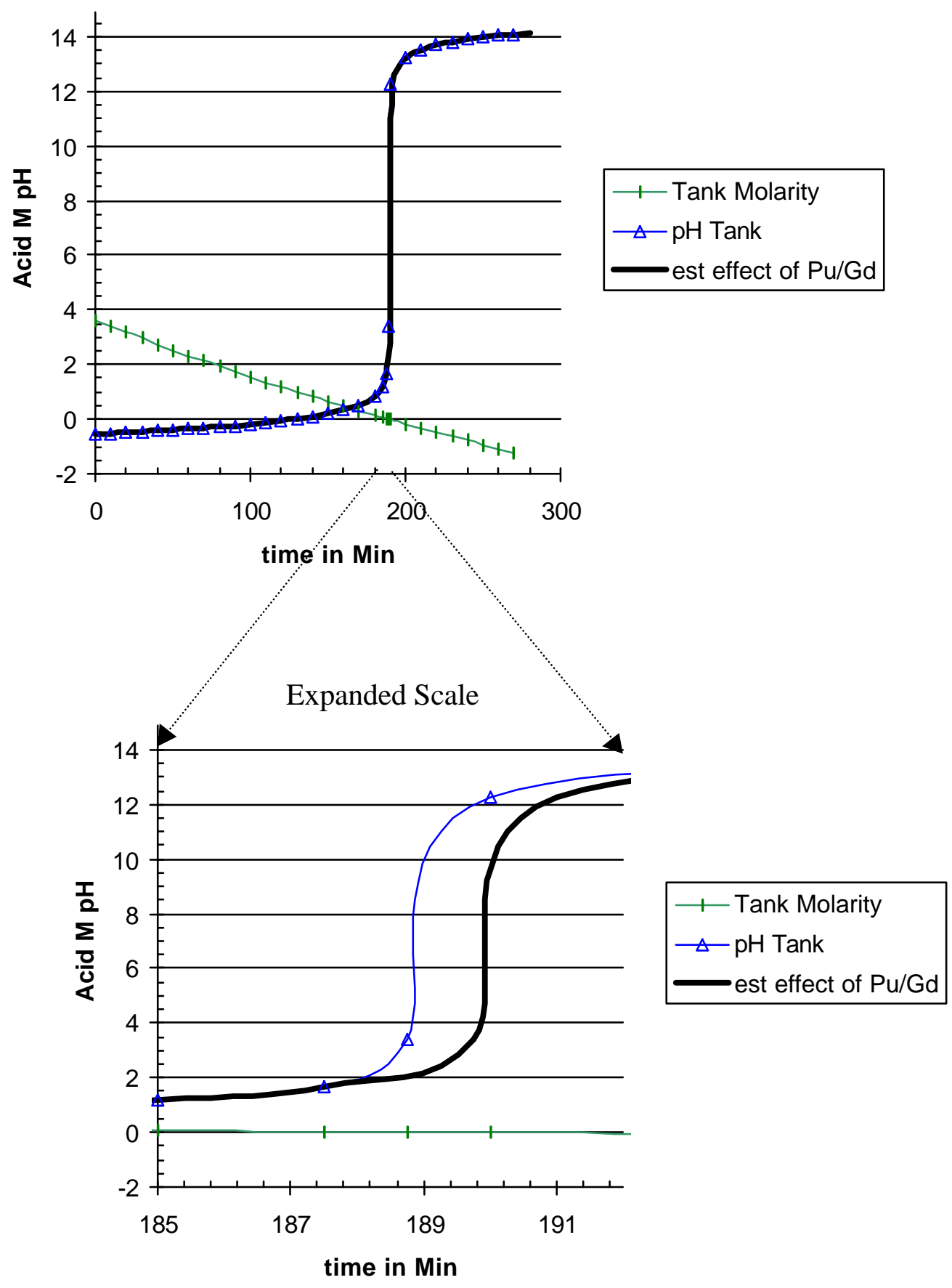




\section{References}

${ }^{1}$ D.T. Hobbs and M.C. Thompson "Technical Evaluation of the Use of Manganese for the Disposition of H-Canyon Mixed Scrap Waste", SRT-LWP-2001-00211, Draft A, December 17, 2001.

${ }^{2}$ R. A. Pierce, "Manganous Nitrate Use in LAP Solutions," SRT-ATS-2000-00038, Rev. 0, March 8, 2000.

3 "Waste Acceptance Criteria for High Level Liquid Waste Transfers to 241-F-H Tank Farms", X-SD-G0001.

${ }^{4}$ E.K. Hyde "Radiochemical Separations of the Actinide Elements," in The Actinide Elements, National Nuclear Energy Series, Div. IV, Plutonium Project Record Vol 14A, G.T. Seaborg and J.J. Kat, Eds (McGraw Hill Book Co, NY 1954 Chapt 15.

5 Actinides In Perspective, Proceedings of the Actinides -1981 Conference, 10-15 ${ }^{\text {th }}$ Sept. 1981, Edelstein ed.1982 Pergamon Press "The Role of W.H. Zarchariasen in Actinide Research", R.A. Penneman pp. 5780.

6 "Criticality of Plutonium Nitrate Solution Containing Soluble Gadolinium", R.C. Lloyd, E.D. Clayton, and L.E. Hansen, Nucl. Sci. and Eng. 48:300-304 (1972).

7 T.L. Fellinger, M.G. Bronikowski, B.C. Hill, J.H.Gray, and D.T. Hobbs, "Demonstration of the Tank Farm Washing Process and the DWPF SRAT Cycle with Sludge Batch 3 Simulant and Precipitated Pu/Gd Mixture from H-Canyon Tank 18.3"; WSRC-TR-2002-00208

${ }^{8}$ X-CLC-H-00231 "H:Pu Atom Ratio in Centrifuged, Neutralized Gd:Pu Precipitate" M G Bronikowski

${ }^{9}$ N-NCS-H-00134 Nuclear Criticality Safety Evaluation: Minimum Safe Gadolinium to Plutonium Ratio in an Infinite System, K. J. McCoid, WSMS

${ }^{10}$ N. E. Bibler, et al, "Behavior of Pu and Gd Mixtures Under Simulated SRAT Conditions", WSRC-TR2002-0211 